\title{
التأمين التكافلي
}

في ضوء أمكام الشريعة الإسلامية

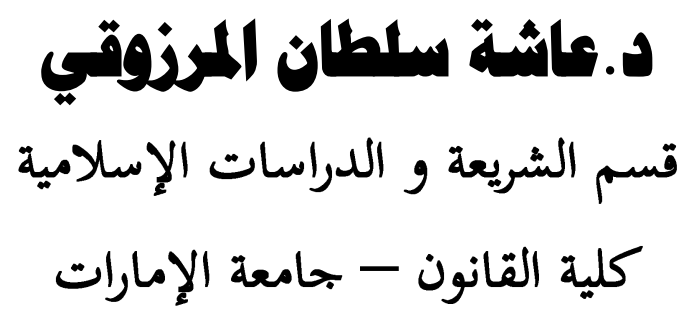

من هrד 1 إلى عVI 
17 r 
أن جميع الأديان السماوية الحقة تدعو إلى الخير، والتعاون غير أن الإسلام قد أولى عناية

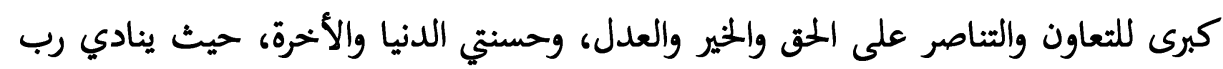

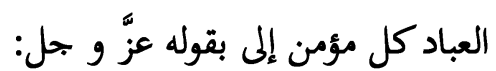

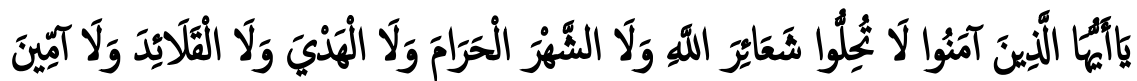

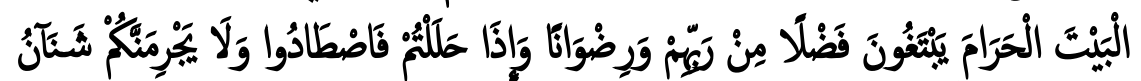

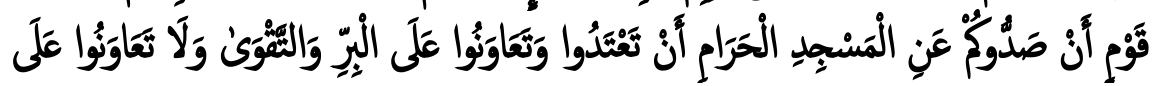

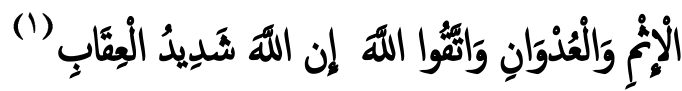

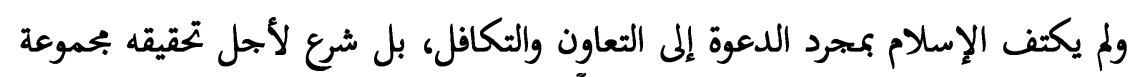

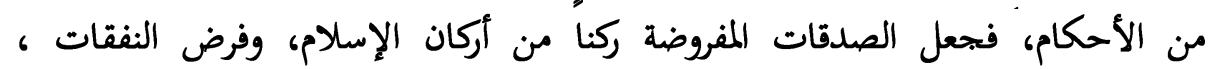
والكفارات ، والحقوق والإلتزامات التي لو طبقت لتحقق التكافل الحقيقي ، وأصبح كل فرد الإدات

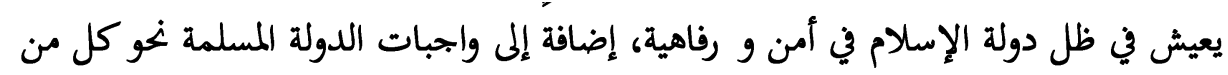

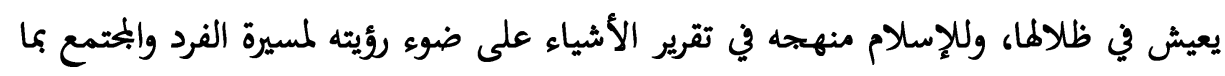
يحقق المصالح الحقيقية لمما ، ويدرأ عنهما المضار والمفاسد.

ومن هنا : إذا نظرنا إلى التأمين كفكرة لتحقيق التعاون ، ودفع شرور الحاجة والعجز

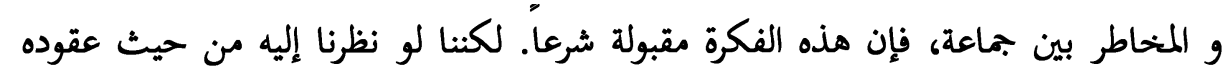

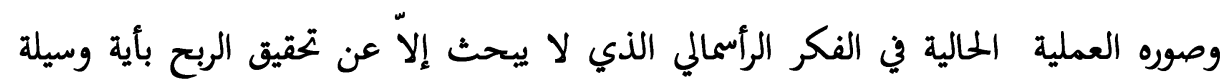

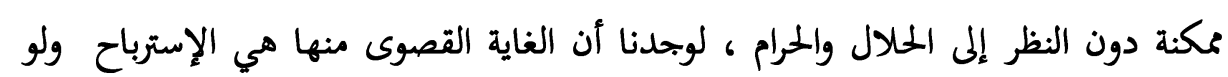
كان مخالفأ لأحكام الشرع . أهداف التأمين التكافلي ووظائفه:

ويستهدف التأمين الإسلامي التكافلي تحقيق عدد من الغايات وبنملها في الآي : 
1- إشاعة الأمن وطمائنينة النفس تجاه أحداث المستقبل وبالتالي تتحقق السعادة المؤمن له، لأنه حين يشعر أن حاجاته تؤمنه في حالات الطوارئ فإن نفسه ترتاح وتطمئن ، وهذه الراحة تعود على المجتمع بالخير. r- التعاون بين أفراد المجتمع، و ذلك ييدو واضحاً في حالة التأمين التعاوني أو التبادلي الذي الذي توزع فيه آثار الأخطار على المجميع و بالتالي يتحصن المحتمع من آثار المصائب والنكبات التي قد تلحق أفراده، وحتى في غير التأمين التعاوين، فإن المؤمن يقوم بدور

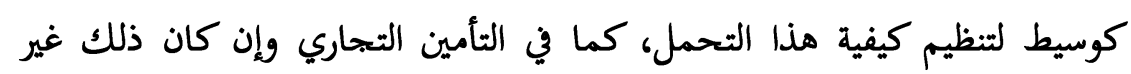
ملحوظ فيه بصورة واضحة، إلا أن النتيجة النهائية له تتمثل في تقسيم آثار الكوارث بين عدد كبير من الناس وهذا هو مؤدى فكرة التعاون"' (1) r- يستخدم التأمين كوسيلة لتشجيع الإتتمان، وذلك أنه عندما يحتاج إنسان إلى قرض من

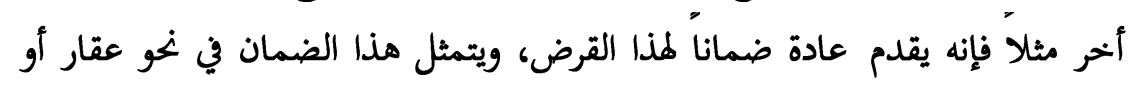

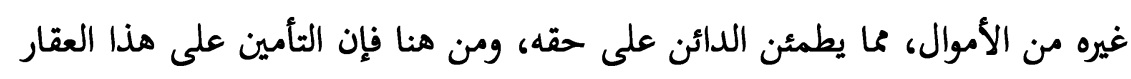
ونخوه من الضياع يؤكد حفظ حق الدائن، وبالتالي يعطي الغرض المطلوب من منه.

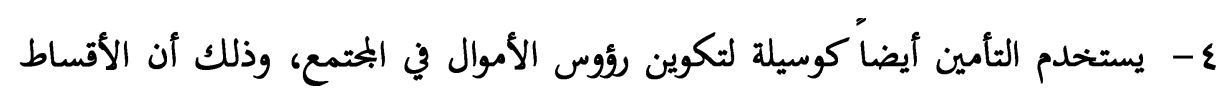
التي ينفقها المستأمنون تتجمع فتكون مبالغ طائلة يمكن الإستفادة بها في المشاريع

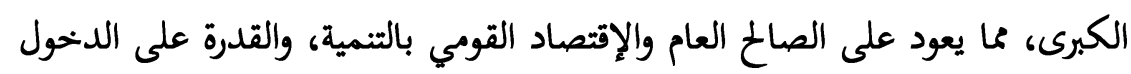

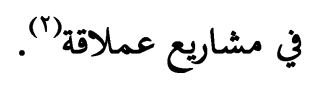

أهمية الدراسة : مزايا التأمين التكافلي أو التأمين الإسلامي :

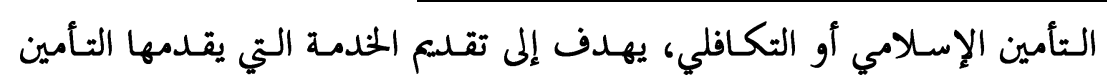

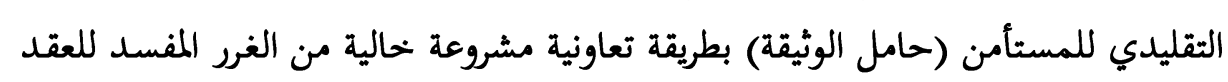

$$
\text { (') (') دراسة شرعية لأهم العقود المالية المستحدثة صناتح ع. }
$$

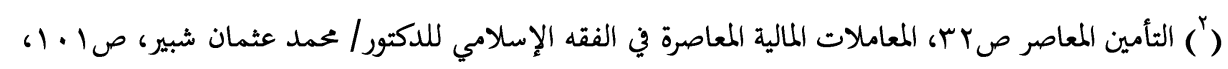


والربا وسائر المخظورات، وذلك بتقليم المستأمن اشتراطات متبرعا بها كليا أو جزئيا لتكوين محفظة تأمينية تدفع منها العويضات عند وقوع الضرر المؤمن ضده. فرضية البحث:

إن غياب التشريع المنظم لأحكام التأمين التكافلي كان سبياً واقعياً في قبول شركات التأمين

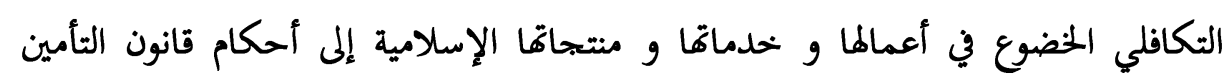
التجاري المعمول بها في مختلف البيئات الإقتصادية، مما دفع الباحثين إلى القول بإزدواجية التعريف و الأركان و الأسس و الشروط و الخصائص المتعلقة بالتأمين التكافلي.

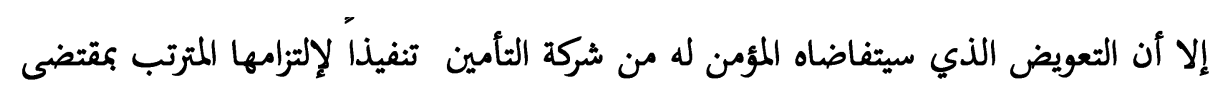
العقد عند تحقق الضرر المؤمن ضده هل يسطبق بشأنه القواعد المقررة للتعويض في التأمين

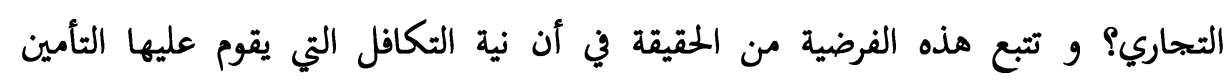
التكافلي تشكل الأساس في تحديد مبلغ التأمين و التعويض القائم على مبنى سد الحاجة و و دفع أثر المخاطر و الكوارث، و ليس بمرد مبلغ التبرع الذي يمثل قسط التأمين؟

ومن هنا نتبع أهمية دراستنا لموضوع : أحكام التأمين التكافلي الإسلامي- دراسة

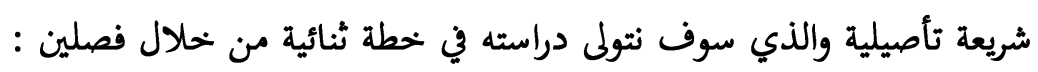
نتناول في المبحث الأول : ماهية التأمين التكافلي المطلب الأول : مفهوم وخصائص التأمين التكافلي. المطلب الثاني : أنواع التأمين التكافلي.

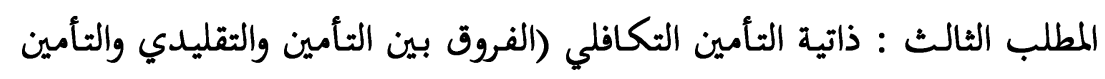
التكافلي) ونتناول في المبحث الثاني : شرعية التأمين التكافلي وتطبيقاته المطلب الأول : الفقه الإسلامي وتطبيق مبدأ التعاون في التأمين. المطلب الثاني : الحكم الشرعي للتأمين التكافلي. 
$17 \varepsilon$.

المطلب الثالث : تطبيقات للتأمين التكافلي 


\section{المبحث الأول}

ماهية التأمين التكافلي الألي

المطلب الأول: مفهوم التأمين التكافلي و خصائصيه

نظراً لحداثة التأمين التكافلي فقد وردت لله تعريفات متعددة نقتصر منها على لئل

مايلي:

1 - قيل إنه: نظام يقوم على التعاون بين بحموعات أو أفراد يتعهدون على وجه التقابل

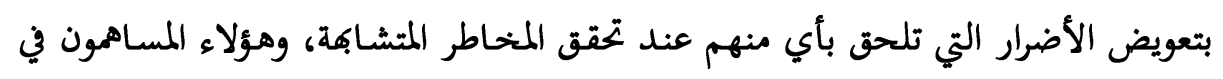

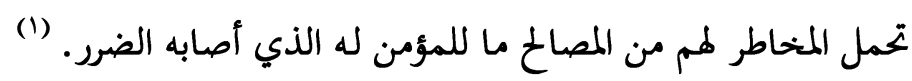

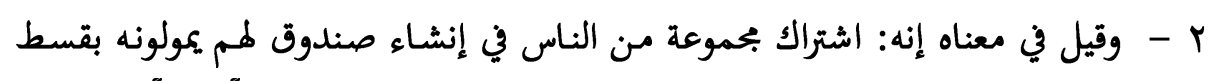

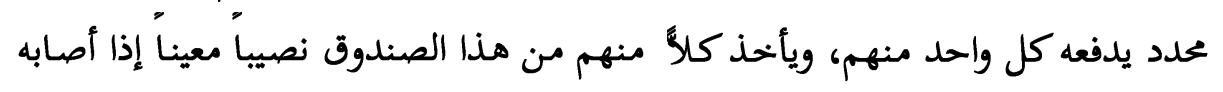
حادث معين. (r) فالتأمين التعاوين بهذا المفهوم لا يهدف إلى تحقيق الربح، بل بحرد رفع الضرر اللآحق بهم.

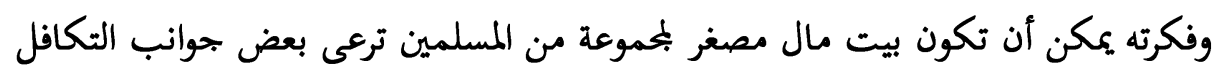
الإجتماعي الأكثر ضرورة عندهم. (")

وأما التأمين التبادلي فهو : "اتحاد غير مقيد، يقوم به المؤمن لهم أنفسهم، فيتعهدون

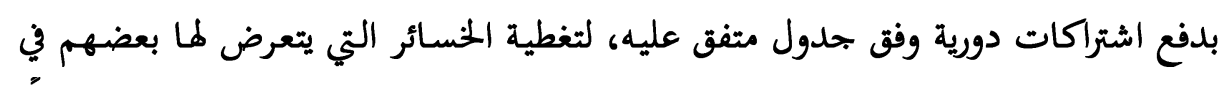

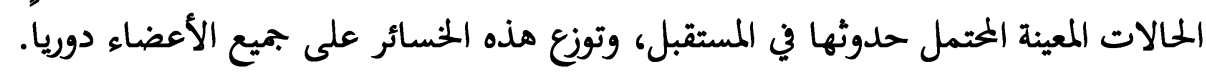

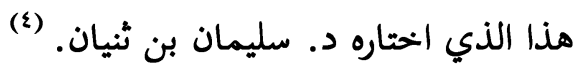

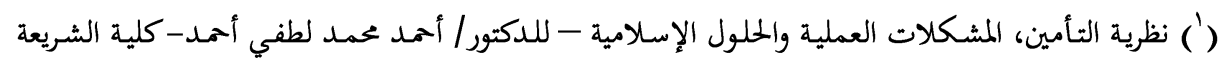

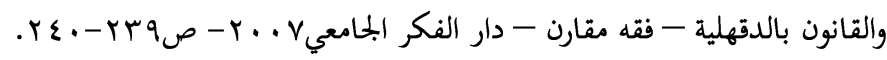

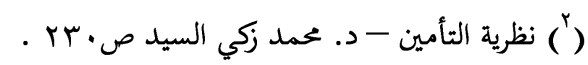

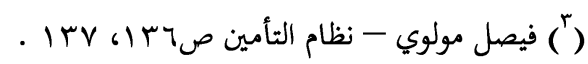

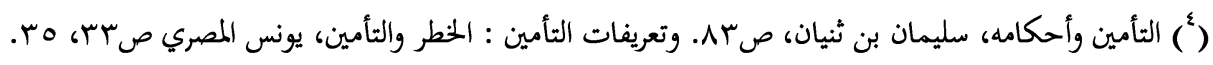


وهناك جمعيات ذات شكل تبادلي، باشتراكات متغيرة أو ثابتة، ويكون لها مال يقدمه المؤسسون، ويقوم مقام رأس المال في شركات التأمين المساهمة. وتمتاز جمعيات التأمين التبادلي عن الشركات المساهمة بأن الأولى لا تعمل للربح

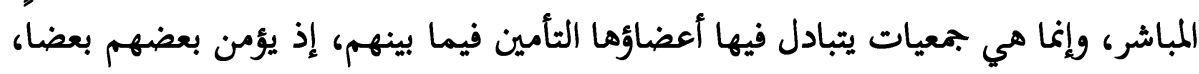
فهم مؤمنون ومؤمن لهم في وقت واحد، ومن هنا وصفت هذه الجمعيات بأها تبادلية. (1)

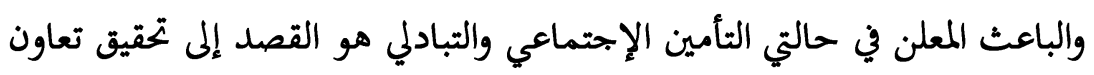
وتضامن بين المشتركين المؤمن لهم، وذلك بتوزيع عبء الأخطار والأضرار التي تنزل بأحدهم عليهم جميعا.

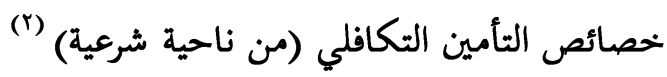
يمتاز عقد التأمين بخصائص منها : أتين 1 أنه عقد ملزم للجانبين (") : و يقصد بأنه بمجرد انعقاده ينشئ إلتزامـات في ذمة طرفيه ، فالمؤمن له ملزم بدفع النهان أقساط التأمين، و المؤمن ملزم بدفع مبلغ التأمين إذا وقع الخطر المؤمن منه. والتزام

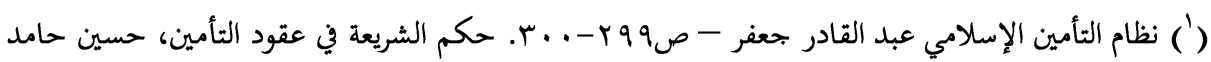

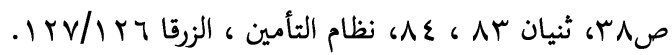

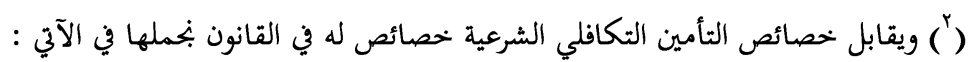

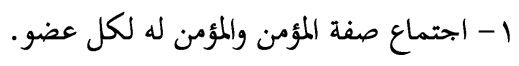
r- ب- بعقراطية الملكية والإدارة.

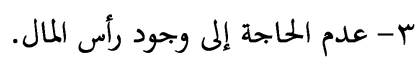
ع- انعدام عنصر الربح. ه- توفير التأمين بأقل تكلفة ممكنة.

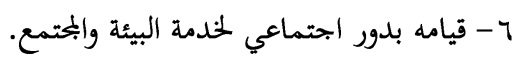

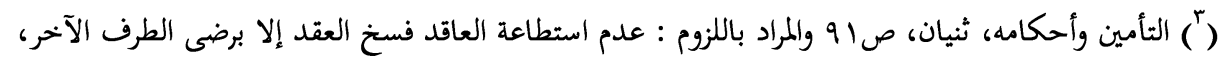

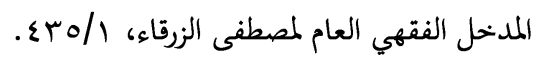


المؤمن له واجب التنفيذ حسب الآجال المعينة، شهرياً أو سنويا أو لسبب خاص (1)،

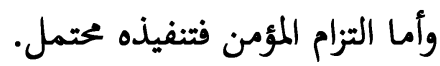

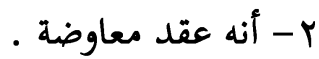

والمراد به هو ما يأخذ فيه كل من المتعاقدين مقابلاً لما يعطي، ومقابله عقد التبرع، وهو

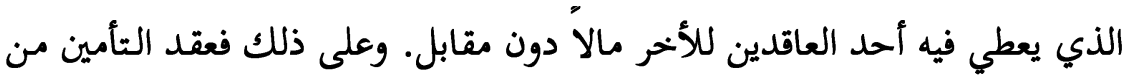

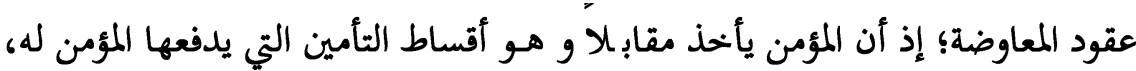

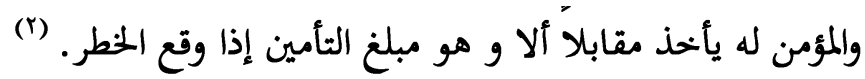

$$
\text { r- r أنه عقد غرر: }
$$

والمراد بالغرر : الخطر، وهو الجهالة بحقيقة الشيء، و وقوعه من عدمه، كبيع السمك

$$
\text { في الماء والطير في الهواء"). }
$$

والغرر قد يكون في حصول الشيء، وقد يكون في أجل حصوله، وقد يكون في قدره.

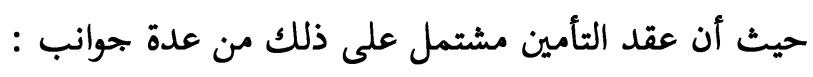

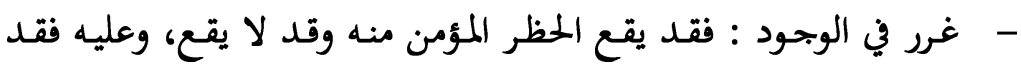
يحصل المؤمن له على مبالغ التأمين وقد لا يحصل. - غرر في الأجل : فأجل وقوع الخطر بجهول، وكذلك أجل التعويض عليه.

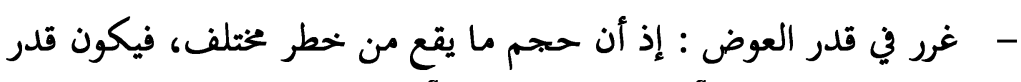

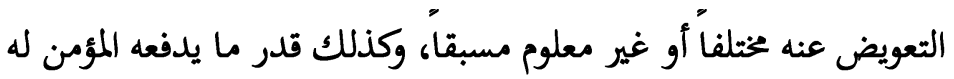
من أقساط للجهل بأجل وظيفته أو حياته ، وهذا الغرر بأنواعه كلها

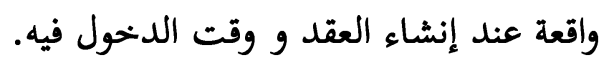

$$
\text { ع- أنه عقد إذعان : }
$$

$$
\begin{aligned}
& \text { (') التأمين على بعض الرحالات الخناصة. }
\end{aligned}
$$

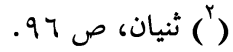

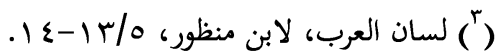


والمراد بعقود الإذعان ما لا تجرى فيه المساومة، كالتي تقع في البيع، وإنما لا يملك فيها

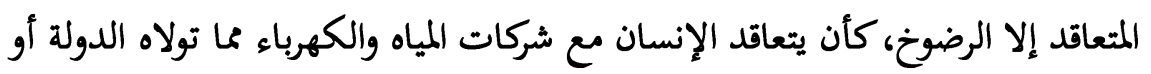

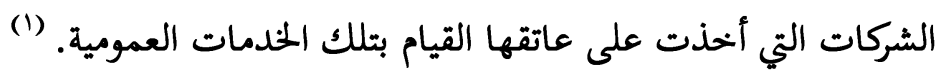

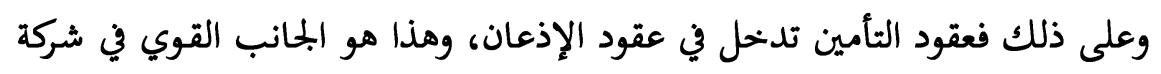

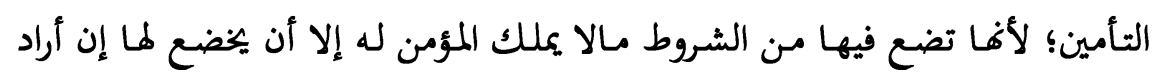
التأمين، فضلاً عن أنَّ الكثير من عقود التأمين إجبارية بحكم القانون.

$$
\text { 0- أنه من العقود المستمرة: }
$$

إذ لا يتم الوفاء بالإلتزام المترتب عليه بصورة فورية، وإنما يستغرق الوفاء به مدة من

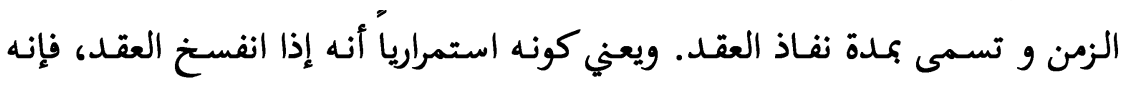

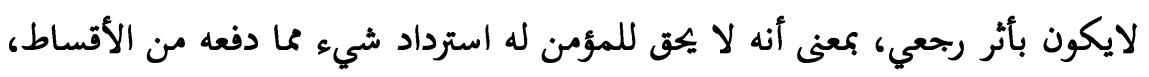
مهما بلغ مقدارها. إما إذا استحال تنفيذ الإلتزام من أحد طرفيه، كأن تَّلفَ العين المؤمن عليها بغير السبب المؤمن ضده، فإن هذا يصادف المستقبل فقط دون الماضي، فيلغى العقد، ولا يحق

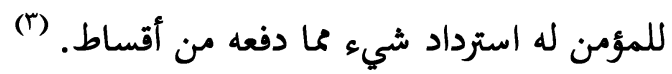

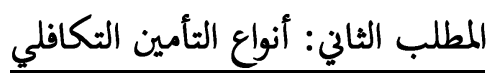

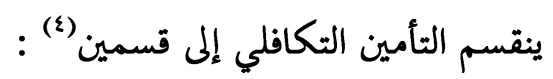

القسم الاول : التكافل التعبدي :

وهو المتمثل في العبادات والشعائر المفروضة على المسلمين، والإسلام يأمر بالتكافل في أداء العبادات، حتى يتحقق معنى العبادة الجماعية التي تختلف عن العبادة الفردية،

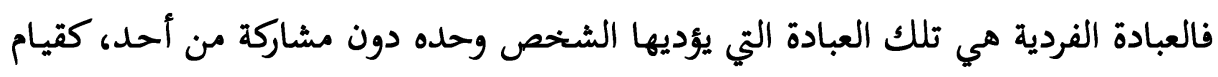

(') ضوابط العقد في الفقه الإسلامي، عدنان خالد التركماني، صهمب، ثنيانبو.

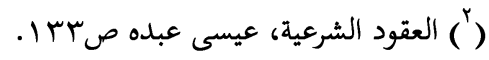

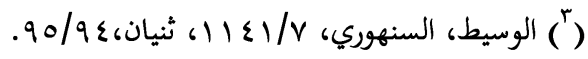

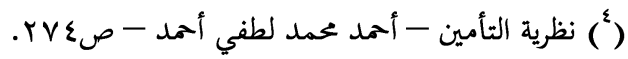


الليل ، وصيام التطوع، أمـا العبادة الجماعية هي التي يشترك في أدائها بجموع المسلمين، كالجماعة في الصلوات وصيام رمضان. وفي القرآن الكريم آيات عديدة تحض على التكافل في آداء تلك العبادات، منها:

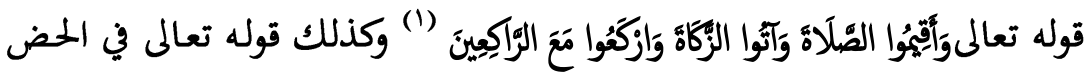

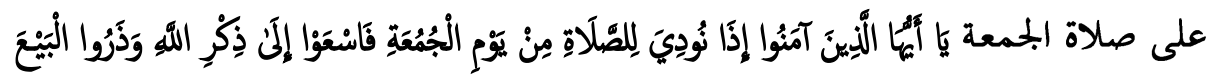

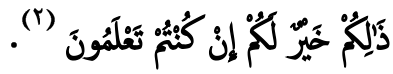
فهذا الخطاب يفيد وجوب صلاة الجمعة كما يطلب حضور صلاة الجماعة، إذ أن

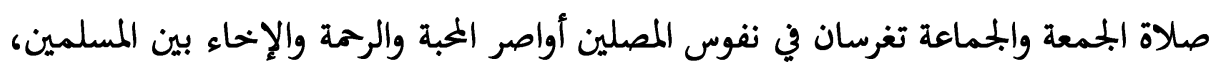
كما أفما يحققان وحدة في العبودية و وحدة في المشاعر، و وحدة في المدف، و وحدة ولهدة في

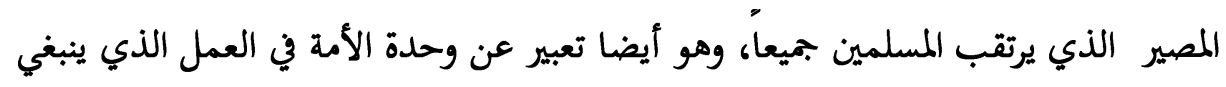

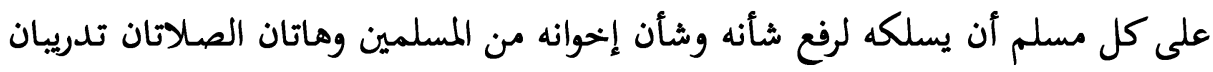

على حب العمل الجماعي الذي ينبغي فعله لصالح الجماعة. (")

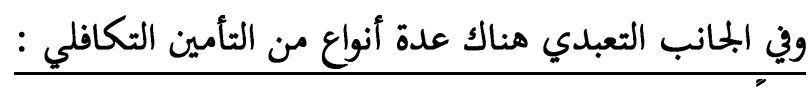

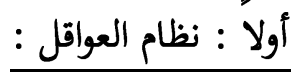

فعاقلة الرجل هم عصبته، وذلك لحديث المغيرة بن شعبة رضي الله عنه: أن الرسول

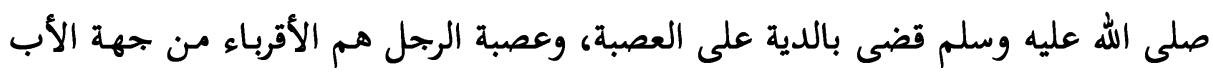

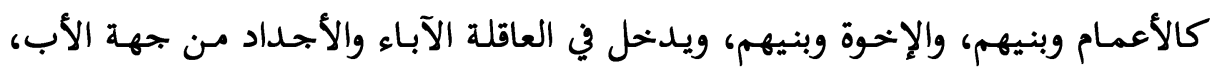

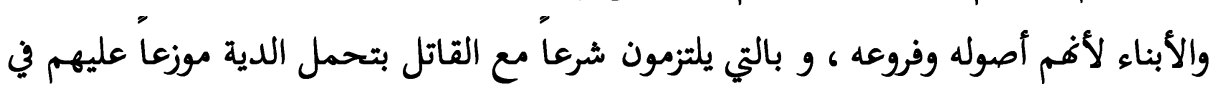

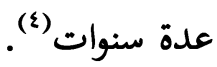

$$
\text { (') (') من الآية رقم بع من سورة البقرة. }
$$

(') التكافل الإجتماعي في الإسلام- داكمال بوزيد، من منشورات بحمع البحوث الإسلامية في المؤتر الثاني عشر 
ثانياً : كفالة الغارمين وأبناء السبيل في مصارف الزكاة :

أوجبت آيه مصارف الزكاة الثمانية في سورة التوبة من القرآن الكريع إعطاء الغارمين

و ابن السبيل من حصيلة الزكاة ما يسد حاجتهم .

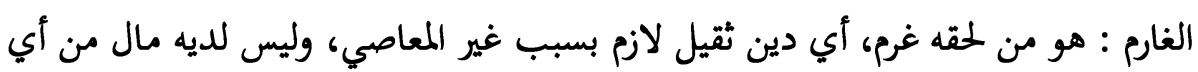
نوع كان يمكنه الوفاء به.

ابن السبيل : فهو الذي انقطع في سفر وهلك ماله فبات غريباً ليس له من يعينه ولا مال معه ينفق منه على نفسه حتى يعود إلى وطنه.

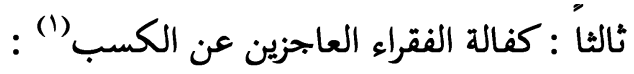

قررت الشريعة الإسلامية حماية الإنسان من خطر العجز عن الكسب في حالة فقره

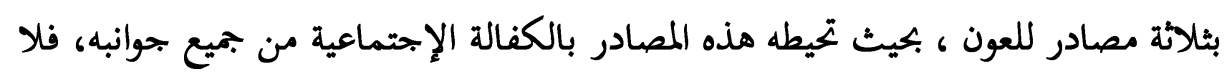
يهمل ولا يضيع.

المصدر الأول: صندوق الزكاة:

ف إن له فيه حقاً بمقتضى فقره. و أن أول مصارف الزكاة ذكراً في آياتا القرآنية هم الزماة: الفقراء و المساكين.

المصدر الثاني: نظام النفقات الوابة بين الأقارب:

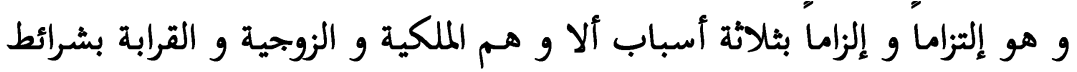

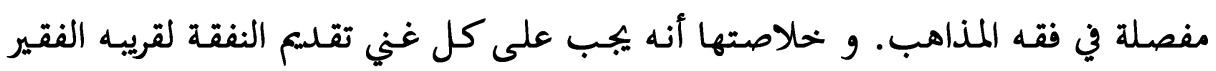

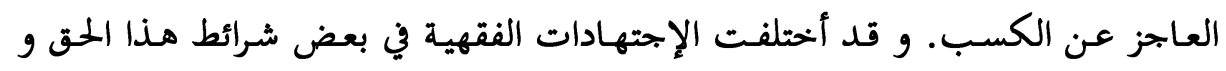
تربيته، و أعدل المذاهب أنه يناط بحق الإرث، فتجب نفقالحتة الفقير العاجز من قريبه الغني

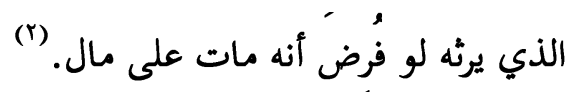

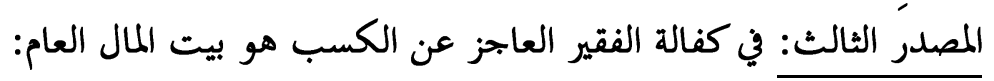

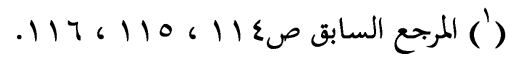

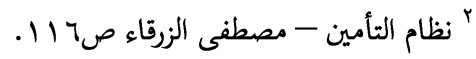


و الأصل في هذا قول الرسول -صلى الله عليه و سلم- :" من ترك مالا فلورثته،

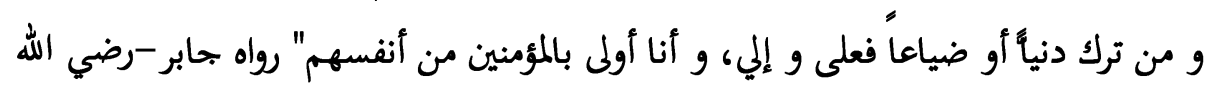

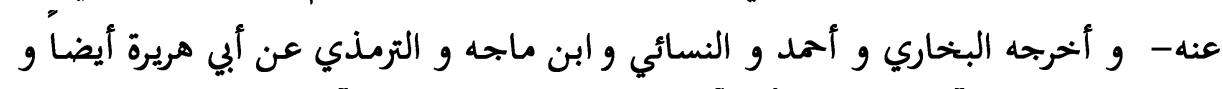

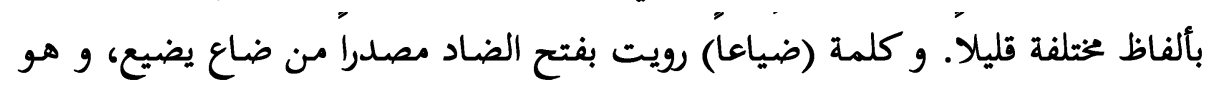

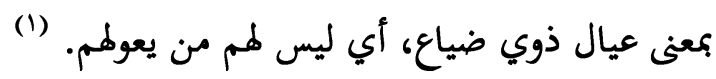

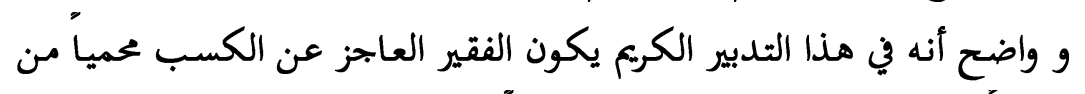

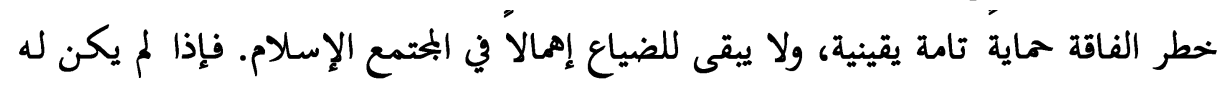

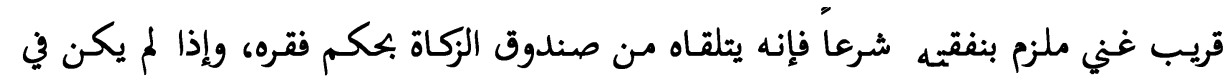

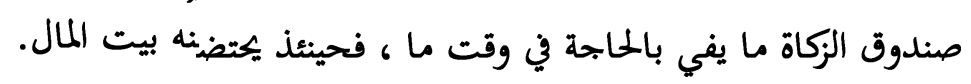
القسم الثاني : التكافل الأسري

بما أن الأسرة هي الدعامة الأول من الدعائم التي يقوم عليها البحتمع المسلم، فقدي

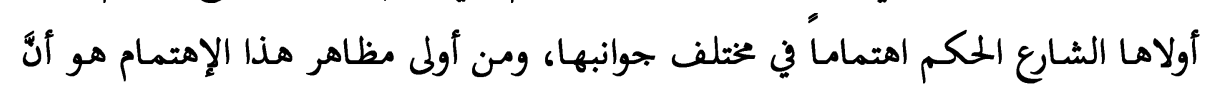

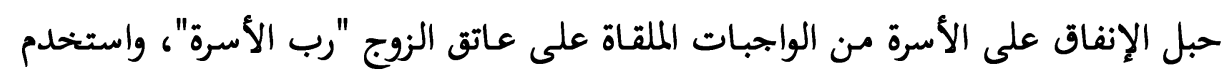

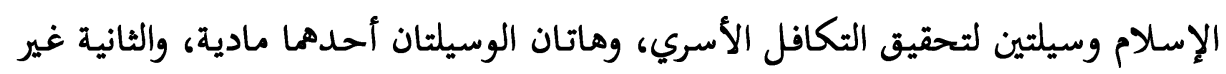

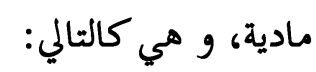
أولاً : الوسائل المادية للتكافل الأسري : تتعدد الوسائل المادية للتكافل الأسري على نهو يجعل أمر الأسرة في ابهى صور الإستقرار،

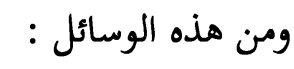

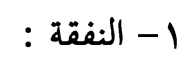

هي الطعام والسكن والكسوة، وقيل هي ما به قوام معتاد حال الآدمي دون إسراف. (r) أنواع النفقة :

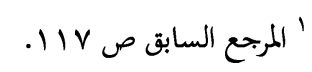

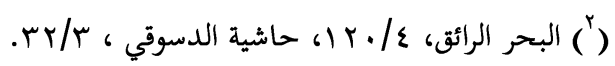


نفقة الزوجة: الإطعام والسكن والكساء، حيث أوجب الله تعالى للزوجة مستلزمات

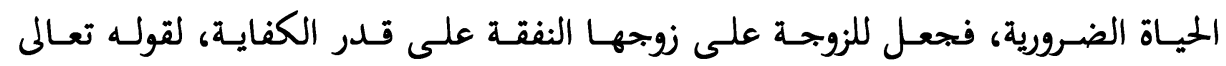

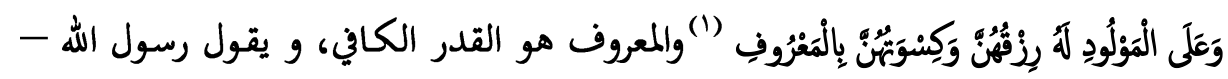

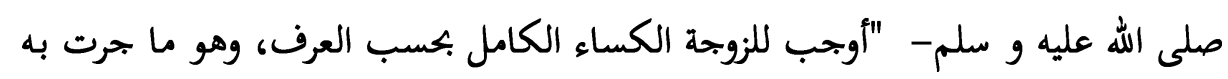
العادة في البلد من ثياب البدن دون إسراف". (r)

كذلك أوجب الإسلام السكنى للزوجة واعتبرها من النفقة الواجبة على زوجها، البها،

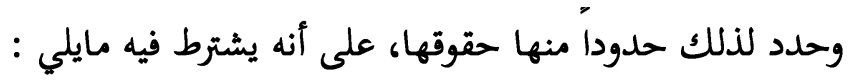
1- أن يكون على قدر حالمما.

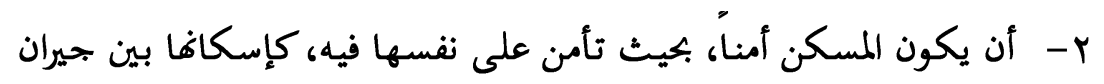

$$
\text { صالحين. }
$$

r- أن يسكن الزوج زوجتهـ في دار مفردة ليس فيها أحـد مـن أهله ، وينظر

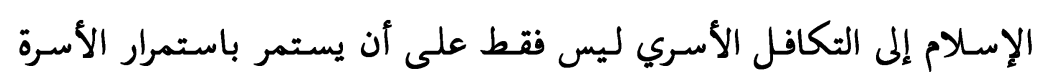

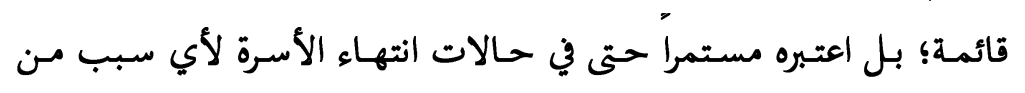
الأسباب.

بل اعتبر الإسلام التكافل حقاً لغير القادرين في الأسرة كالأطفال حتى لا يضيعوا في غياهب الحياة، فقرر حق الرضاع للطفل كأحد التأمينات الأساسية

$$
\text { الملقاه على عاتق رب الأسرة. }
$$

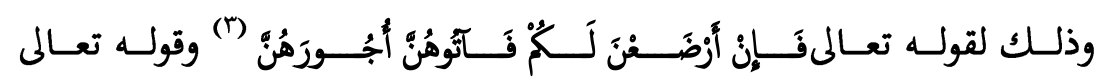

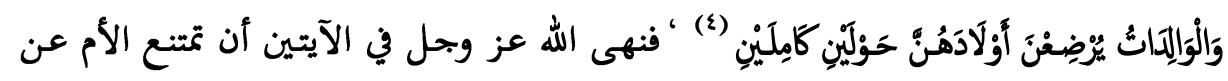

(') جزء الآية rrr من سورة البقرة، وقوله صلى الله عليه و سلم لمند بن عتبه رضي الله عنها خذي ما يكفيك

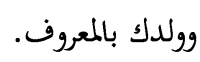

(') الحديث أخرجه البخاري، كتاب النفقات، باب إذا لم ينفق الرجل فللمرأة أن تأخذ بغير علمه ما يكفيها

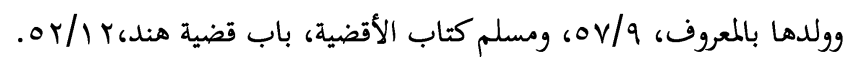

$$
\begin{aligned}
& \text { () () جزء الآية } 7 \text { من سورة الطلاق. } \\
& \text { () صدر الآية رقم بrr من سورة البقرة. }
\end{aligned}
$$


إرضاع ولدها إضرارا بأبيه، أو تطلب أكثر من أجر مثلها، ولا يجوز للأب أن ينزع منها الولد

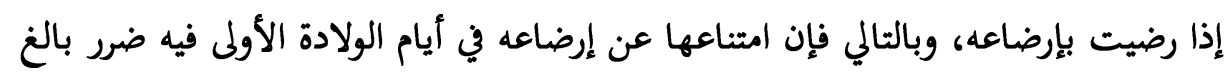

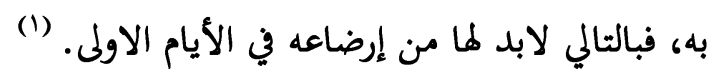

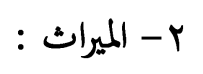

يعتبر حق الميراث من أبرز صور التأمين التي كفلها الإسلام لبني البشر، إذ بهذا

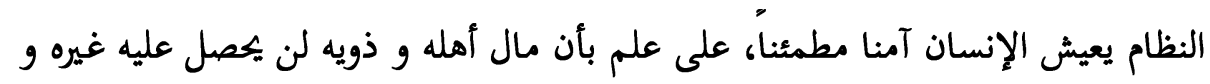

$$
\text { من معه ممن يكون لمم الحق فيه. }
$$

ولعل أهم صورة تظهر وجود التأمين في نظام الإرث الإسلامي هي ما قرره الإسلام

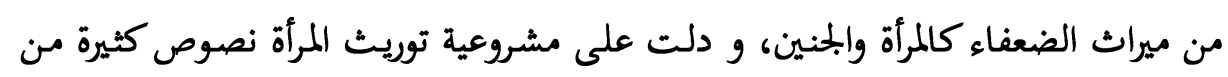

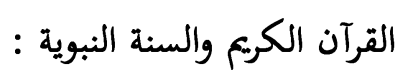

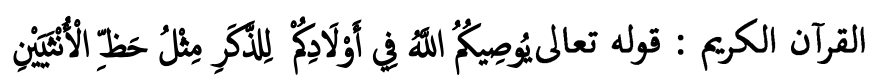

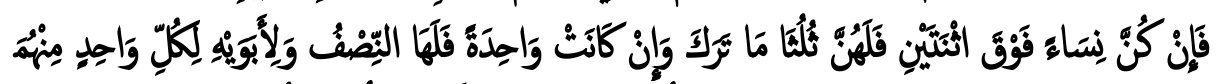

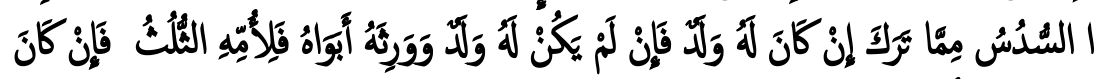

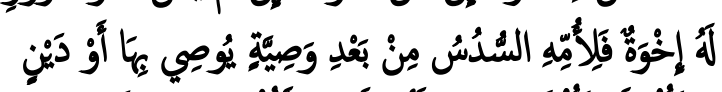

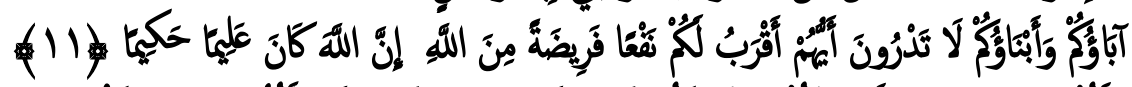

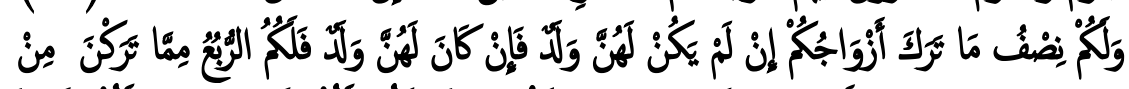

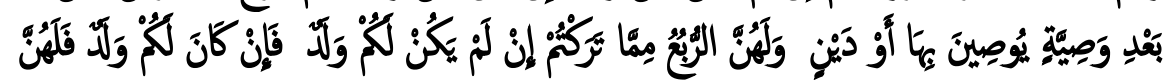

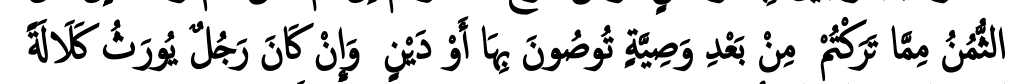

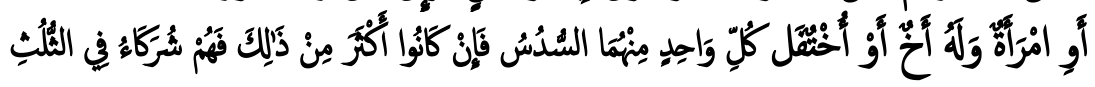

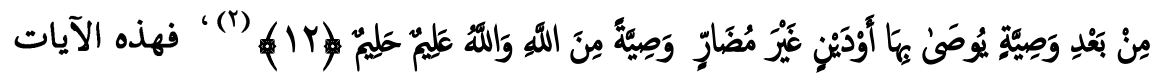
تظهر وبيكلاء أن ميراث المرأة حق مقرر من قبل الشارع فلا يجيوز بأي حال من من الأحوال

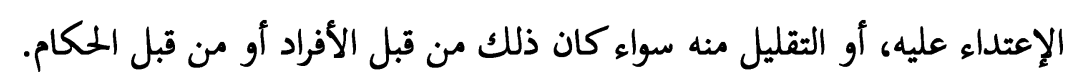

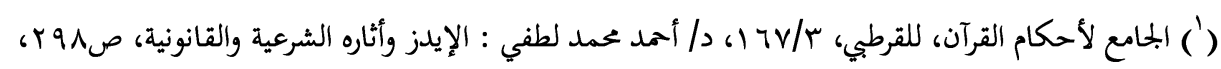

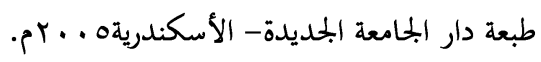

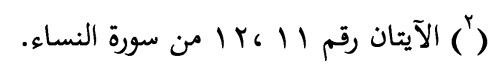


ومن السنة : قول النبي -صلى الله عليه و سلم- "ألحقوا الفرائض بأهلها فما بقى فالأولى رجل ذكر" (1)

والسنة فصلت بحمل الكتاب في شأن الميراث - وغيره- وذلك كميراث الأخت أو

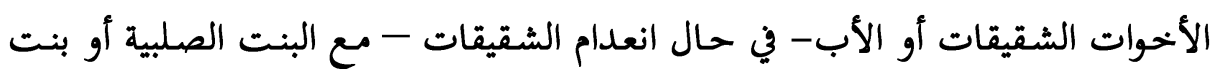

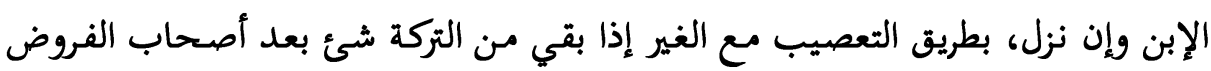
،وكميراث بنت الإبن مع البنت الصلبية .

ولعل في تقرير الإسلام لميراث المرأة أكبر دليل على كفالة الإسلام لما، كما أن نظام

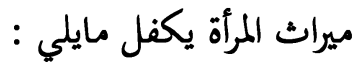
ا - التأكيد على إنسانية المرأة وأغها شق الرجل ، وأثما أهلاً للإستحقاق والتملك والتصرف كالرجل تماماً ، وفي هذا من التكريم للمرأة ما فيه. r- إن الله عز وجل قد جعل الإنسان في الأرض خليفة ، فوكل إليه مهمة عمارتما واستنباط خيراتها ، و زوده بقدرات تمكنه من القيام برسالته ، ولفظ

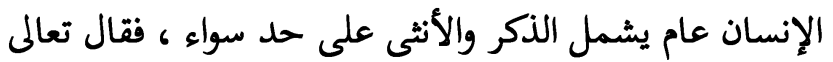

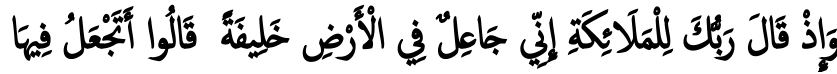

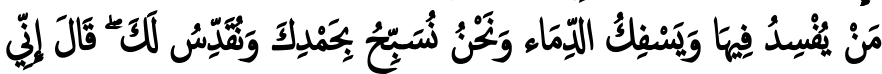

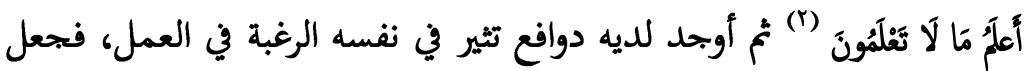

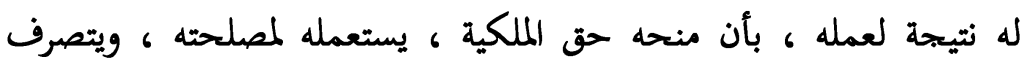

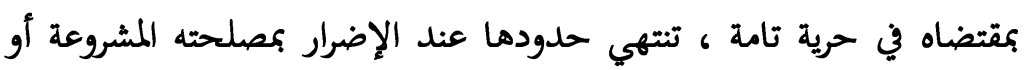

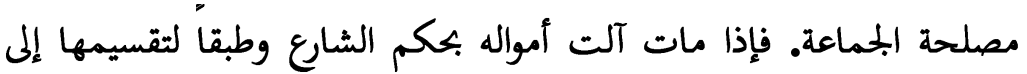

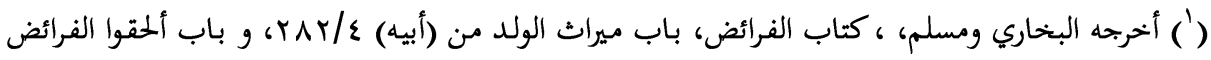

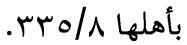


أقرب الناس ومن تعتبر حياتمم إمتدادا معنوياً لحياته من أولاد وأقارب، ذلك كله من أجل أن يتحقق هدف عمارة الأرض. r- تمليك الإسلام للمرأة فيه عون لها على قضاء حوائجها.

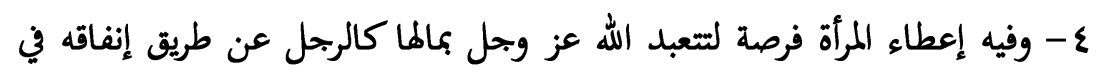
وجوه الخير المختلفة. ه- إن حصر الميراث بالذكور قد يؤدي بهم إلى الشعور بالعظمة ، ويربي لديهم

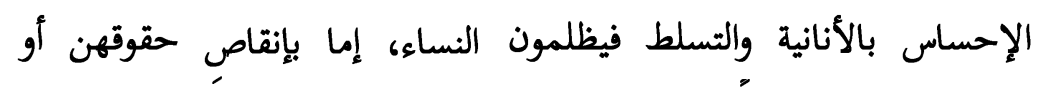
بحرمافن مما لمن مطلقا. ج- التنصيص على حق المرأة في الميراث - كبيرة كانت أو صغيرة - في كتاب الله

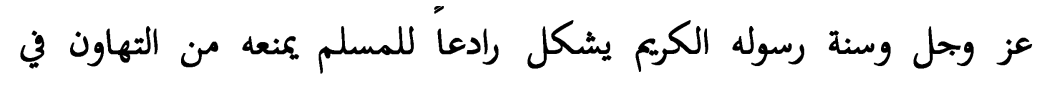
إعطائها ما لما من حق في مال المتوفى .

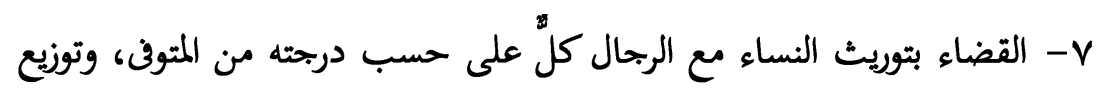

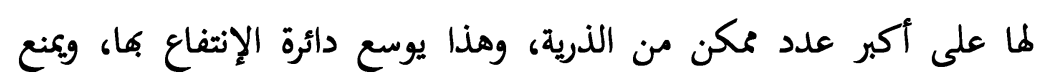

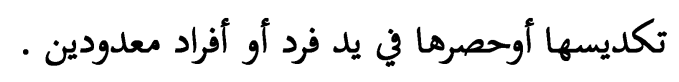

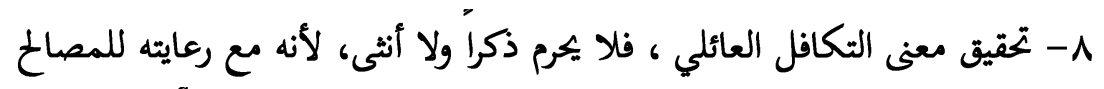

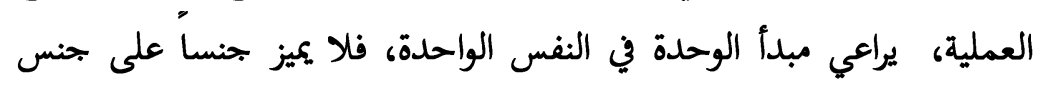
إلابقدر أعبائه (1) 


\section{المطلب الثالث: الفروق بيز التامين التقليدي والتامين}

(1)

التكاضلي

ا - إن محفظة التأمين ليست مستقلة عن أموال الشركة في التأمين التقليدي، فجميع مـا

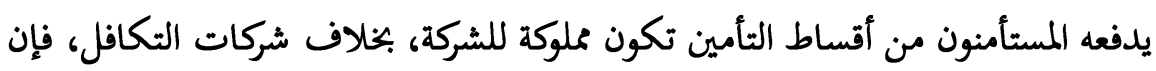

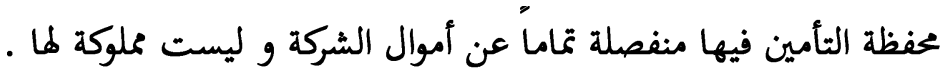
r - إن عقد التأمين التقليدي عقد معاوضـة بين المستأمن والشركة، يدفع حامل الوئيقة

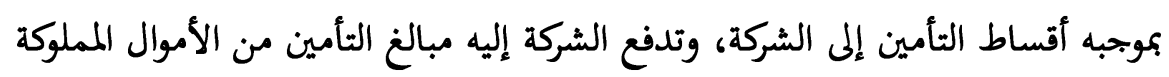

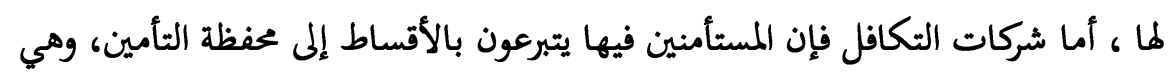
تتبرع إليهم بالتعويضات حسب شروطها . r- في التأمين التقليدي، الأرباح الحاصلة من استثمار الأقساط كلها مملوكة للشركة بحكم

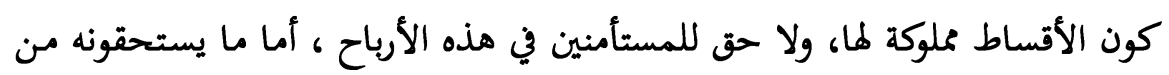

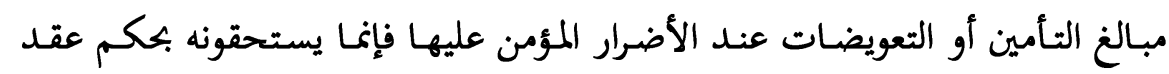
التأمين، لا من حيث إفم مساهون في الإستثمار، بخلاف شركات التكافل فإن أرباح

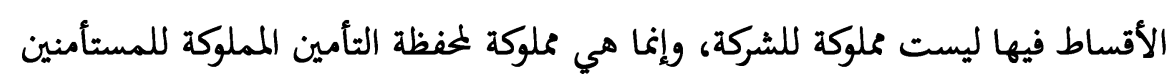

ع - لا يستحق المستأمنون في التأمين التقليدي أية حصة في الفائض التأميني، فإنه بأسره

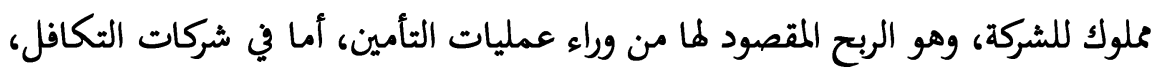

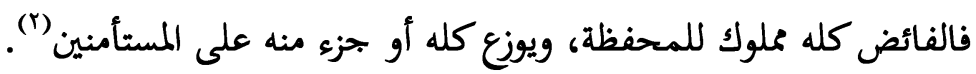

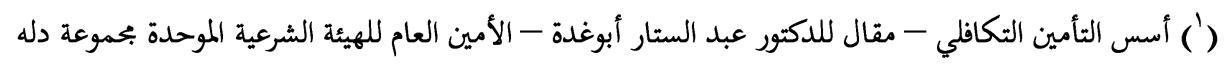

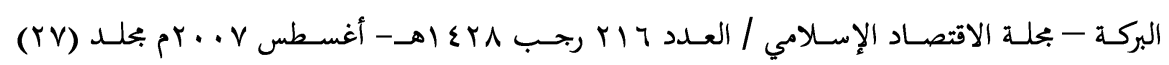
ص( • ( ). (') من بحث البروفسور الصديق محمد الأمين الضرير. 


$$
\text { الفقرة الأولى: الأسس المعنوية للتأمين التكافلي في الإسلام }
$$

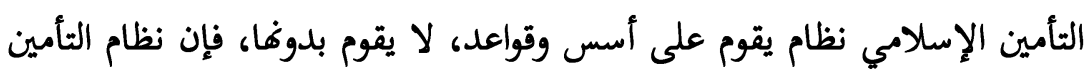

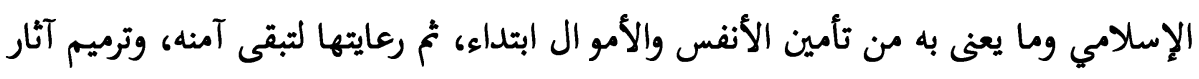

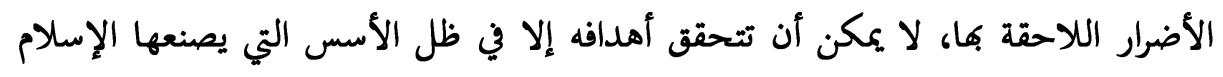

\section{الأساس الأول : العقيدة الإسلامية الصحيحة :-}

وهي :

من العقيدة الراسخة عند المسلمين، أن المسلم لا يخاف موتأ، ولا فقراً، ولا مرضاً،

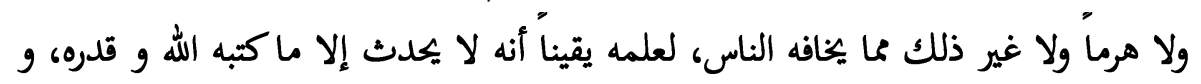

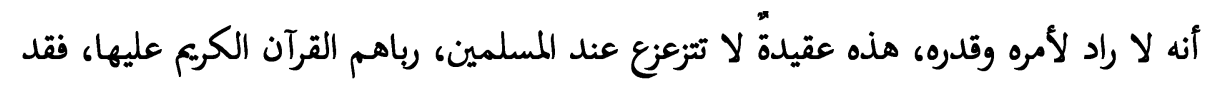

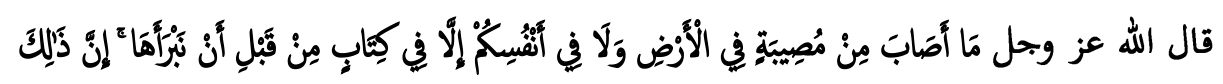

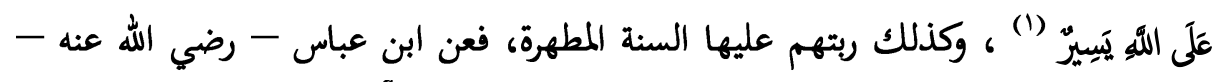

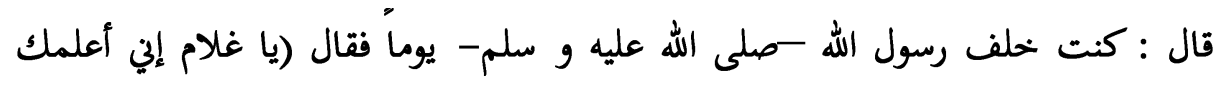

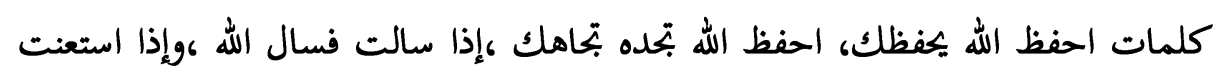

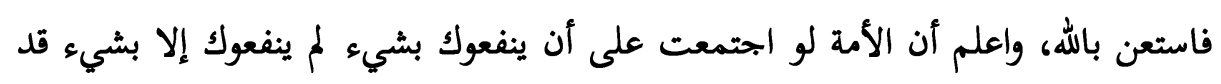

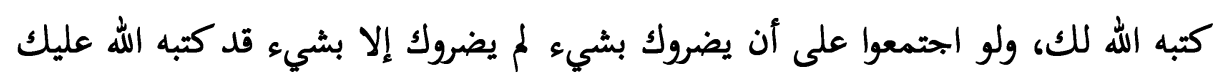

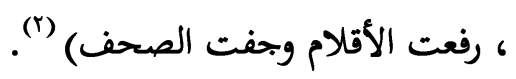

الأساس الثاني : قيام الدولة الإسلامية والعمل بشريعة الإسلام :

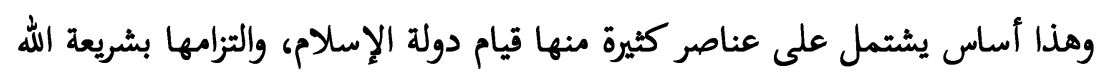

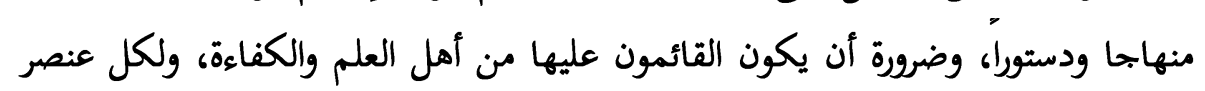
أهميته في تأمين الأنفس والأموال بالمفهوم الإسلامي الشامل. الأساس الثالث : الإقتصاد الإسلامي والتنمية الشاملة :

$$
\text { (') (') سورة الحديد : من الآية (Yr). }
$$

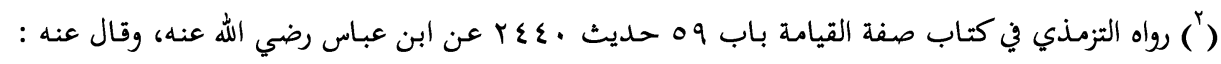


وذلك أن تلتزم الأمة في اقتصادها بأحكام الإسلام، مع الإستفادة من الخبرات

العالمية في كل ما لا يتعارض مع المبادئ و الأحكام الشرعية.

الأساس الرابع : قيام المجتمع على أساس الأخوة الإسلامية:

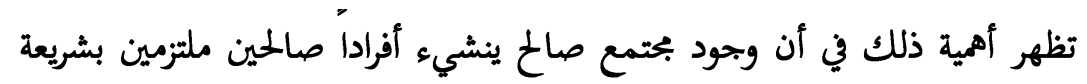

الإسلام في أقوالهم وأفعالهم، وفي جميع تصرفاتم وعلاقاتم فيما بينهم. فقيام بجتمع صالح

ضرورة، لأن الفرد يتأثر بالمحتمع. (1)

الأساس الخامس : التربية الإسلامية المادفة و أهميتها في التأمين الإسلامي : التربية هي عملية بناء للفرد والمحتمع وفق صياغة قائمة على مفاهيم عقائدية وأخحلاقية محددة، فإذا كانت التربية إسلامية فإن ارتكاز هذه الصية الصيغة ستكون بناء على الى

مفاهيم الإسلام العقائدية والفكرية والمسلكية.

الفقرة الثانية: الأسس المادية للتأمين التكافلي في الإسلام

1- إقامة التأمين التكافلي على أساس الوقف :

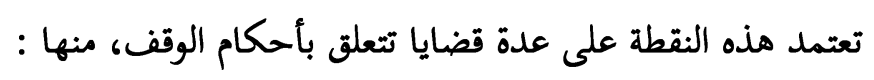

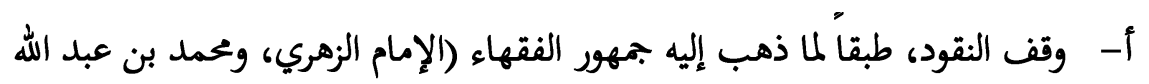

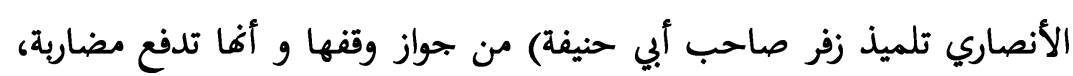

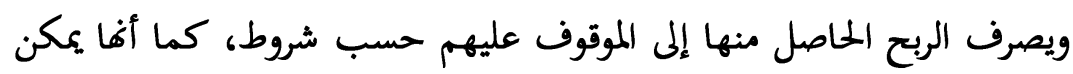

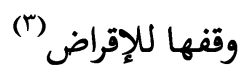

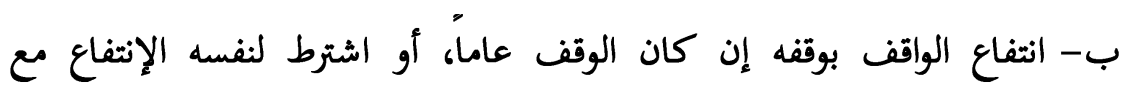

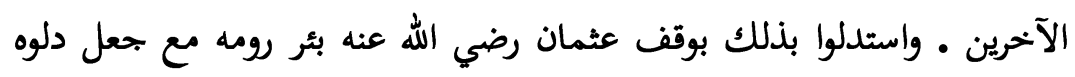

كدلاء المسلمين. (๕) (

(') أصول الدعوة، عبد الكريع زيدان، صه بان ا. (')

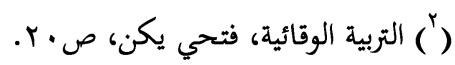

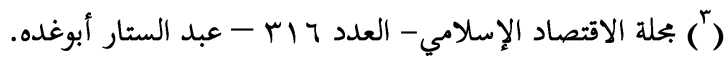

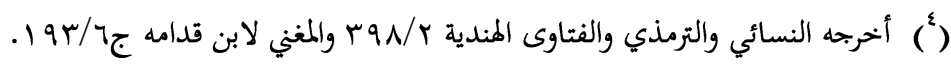


ج- ما يتبرع به للوقف لا يكون وقفا، بل هو مملوك للوقف يصرف للموقوف عليهم،

$$
\text { ولمصالح الوقف. (1) }
$$

د- لا بد في الوقف أن يكون لمهة لا تنقطع باتفاق الفقهاء. (r)

تطبيق صيغة الوقف على التكافل (")

وعلى أساس هذه المبادئ يمكن إنشاء صندوق التأمين على أساس الوقف بالشكل

1- تنشيء شركة التأمين الإسلامي صندوقاً للوقف، وتعزل جزءاً معلوماً من رأس مالما

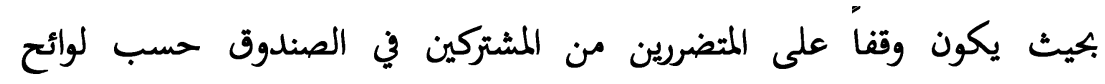
الصندوق، ويكون ذلك من باب وقف النقود ، فيبقى هذا الجزءء المعلوم من النقود

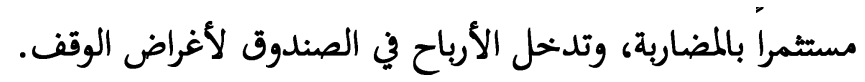

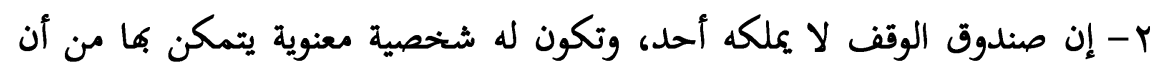

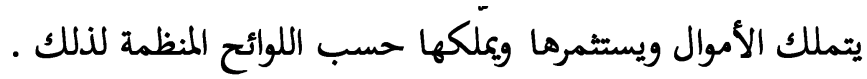
r- الراغبون في التأمين يشتركون في عضوية الصندوق بالتبرع إليه حسب اللوائح •

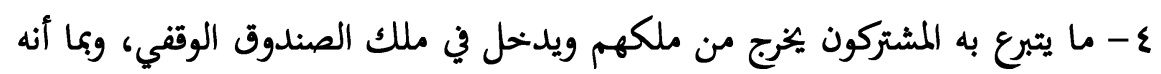
مملوك للوقف ، فلا يجب الإحتفاظ بمبالغ التبع كما يجب في النقود الموقوفة، وإنما

$$
\text { تستثمر لصالخ الصندوق. }
$$

ه - تنص لائحة الصندوق على شروط استحقاق المشتركين للتعويضات، ومبالغ التبرع

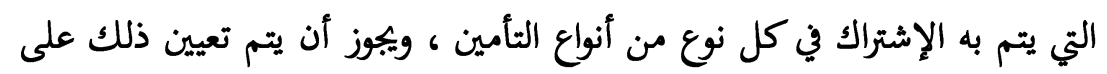
الحساب المعمول به في شركات التأمين التقليدية .

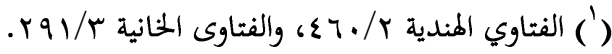

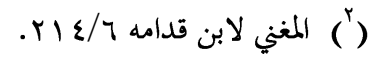
(') بحث (تأصيل التأمين التكافلي على أساس الوقف) للقاضي الشيخ محمد تقي العثماني. 
7 - ما يكعل عليه المشتركون من التعويضات ليس عوضا عما تبرعوا به، وإنما هو عطاء

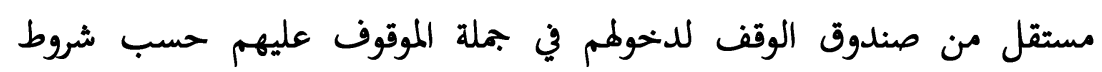
الوقف. V- يجب أن ينص في شروط الوقف أنه إذا صفّي الصندوق، فإن المبالغ الباقية فيه بعد تسديد ما عليه من التزامات تصرف إلى وجه غير منقطع من وجوه البر. r-إقامة التأمين التكافلي على أساس المضاربة :

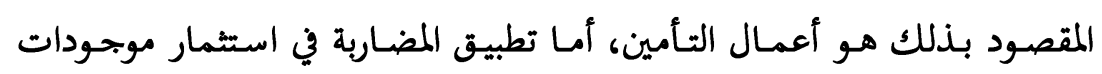

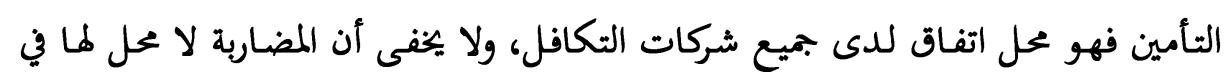

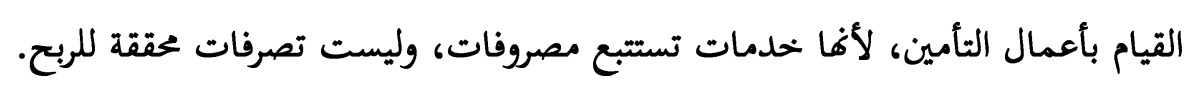
ثم إن إعطاء جزء من الفائض على أنه حصة المضارب من الربح غير مستقيم، لأن

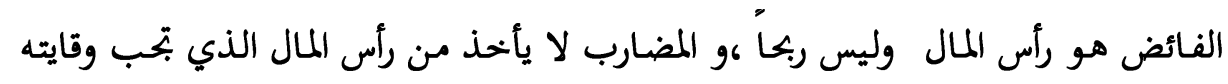
وسلامته للإعتراف بوجود ربح زائد عنه قابل للإقتسام بين المضارب وأرباب المال . وقد قامت هيئة المحاسبة والمراجعة للمؤسسات المالية الإسلامية عند إعداد عدد

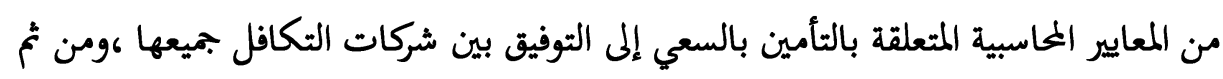

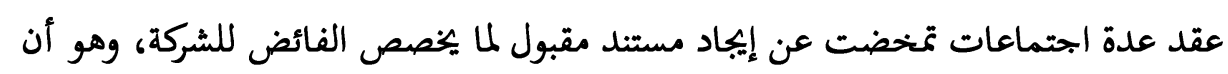

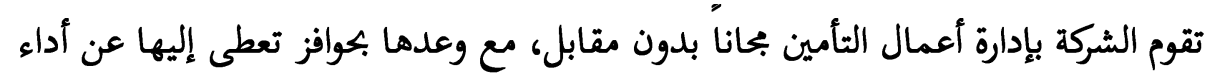

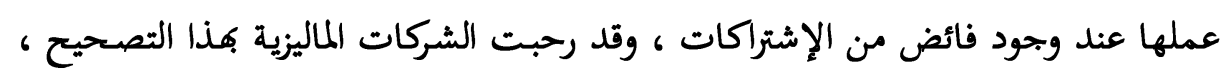

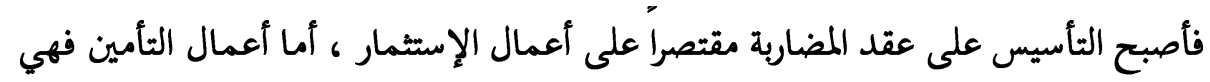

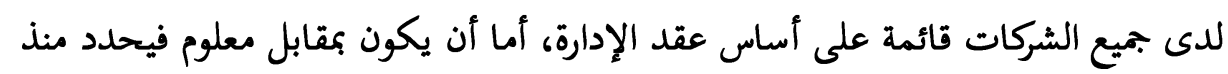

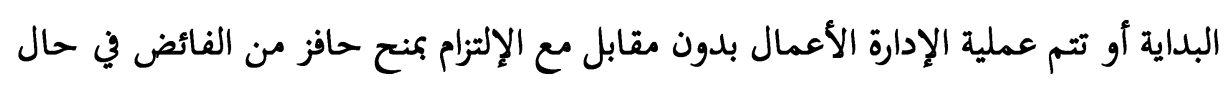

\section{r- إقامة التأمين التكافلي على أساس التبرع أو التزام التبرع :}

التكييف الشائع للتأمين التكافلي الذي اختاره جمع من العلماء المعاصرين هو أن

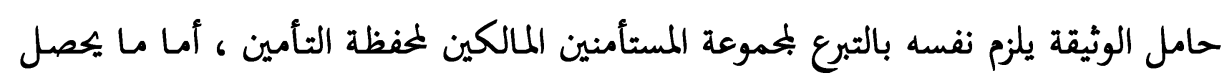




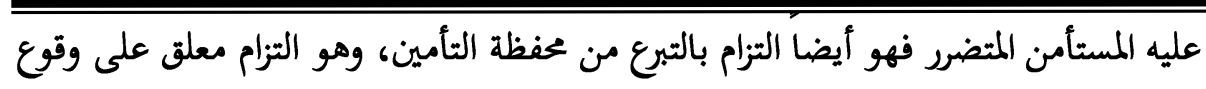
الضرر المؤمن منه ، وهذا التكييف مبني على أصل المالكية : ( من ألزم نفسه معروفاً لزمه ) . . تطبيق ( التزام التبرع ) على التكافل : 1- تُشأ محفظة للتأمين، ويطلب من طالبي التأمين ( المستأمنين ) أن يتبرعوا بأقساط التأمين

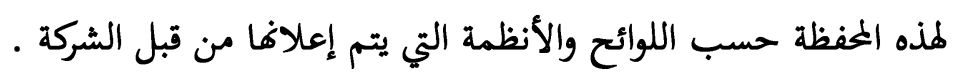
r- الشركة لا تملك محظظة التأمين، ودورها بالنسبة لإدارة المخفظة ينحصر في إنشاء حساب

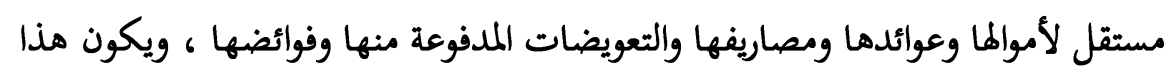

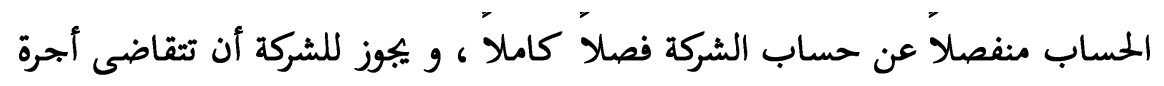

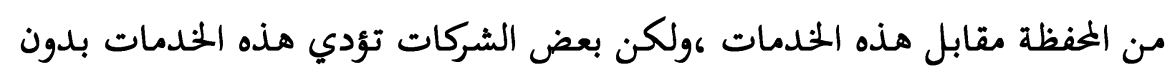

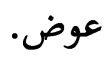
r- بحفظة التأمين تتزايد مبالغها بتزايد المستأمنين، وبالعوائد التي تكتسبها من استمار أموالما

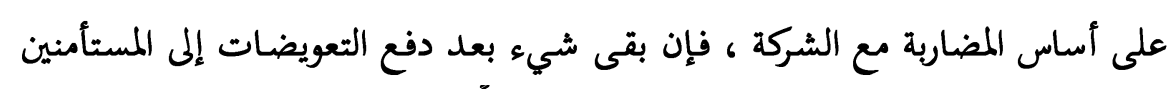

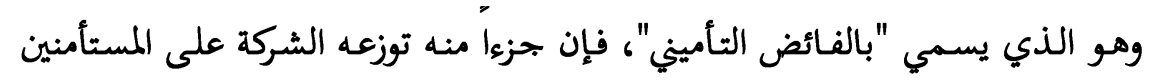

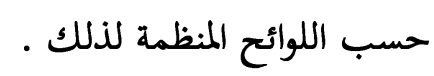

ع - الشركة تقوم باستثمار أموال الحفظة على أساس المضاربة الشرعية، تكون هي فيها

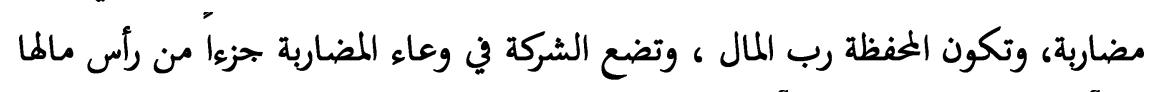

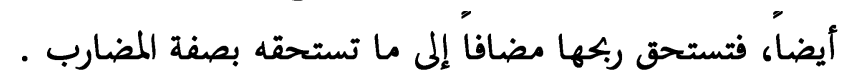


المبحث الثاني

شرعية التأمين التكافلي وتطبيقاته

التأمين التكافلي هو التعاون في درء الأخطار بين أفراد الجماعة الواحدة ، وينشأ

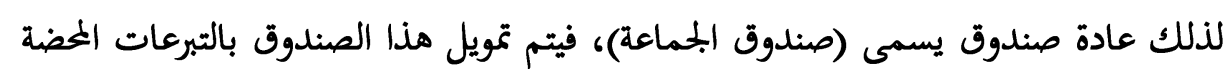

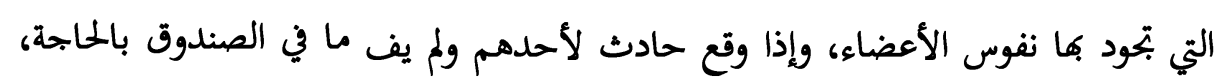

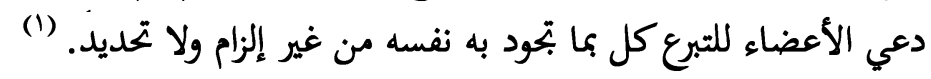
المطلب الأول: الفقه الإسلامي وتطبيق مبدأ التعاون في التأمين

هذا النوع من التأمين هي الصورة الوحيدة التي تقوم على التعاون الإقتصادي لكون

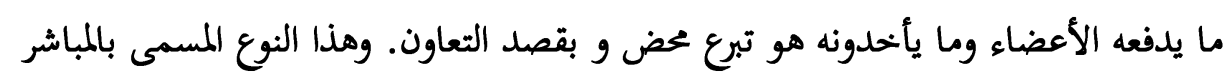

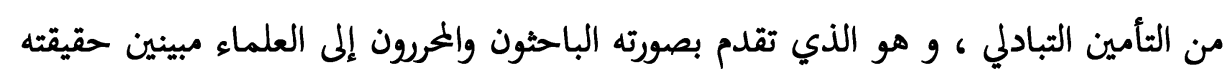
كواجهة تمثل التأمين التبادلي المباشر والمتطور، دون أن ييينوا حقيقه المتطور منه. هذا رغم أن الفرق بينهما شاسع، و رغم أن التطور هو وحده الغريب عن العلماء،

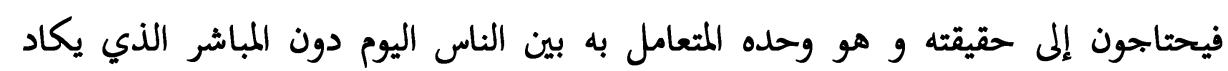

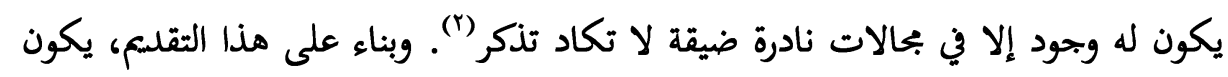

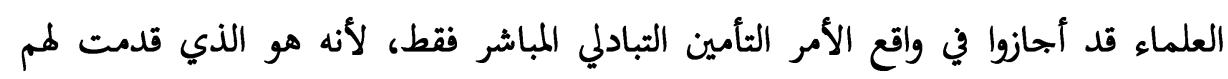
صورته وبينت لهم حقيقته دون المتطور الذي خفي عليهم أمره.

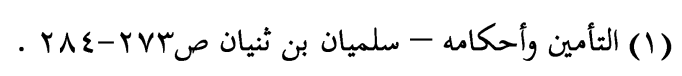

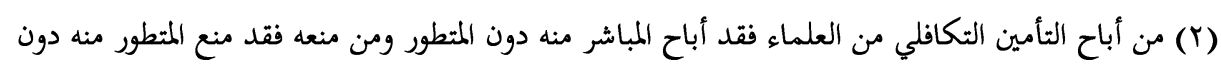

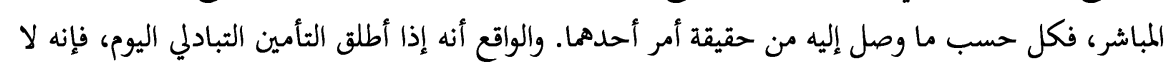

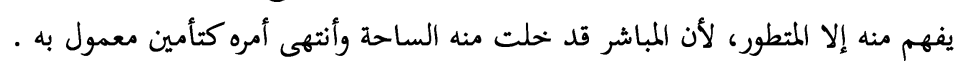


وحجتهم في إباحة المباشر : أنه تبرع محض، لا يدخله الربا ولا سائر المخظورات

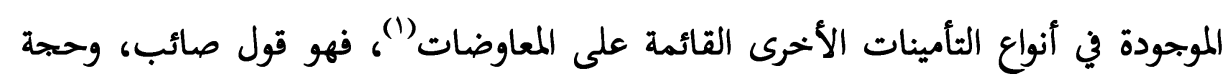

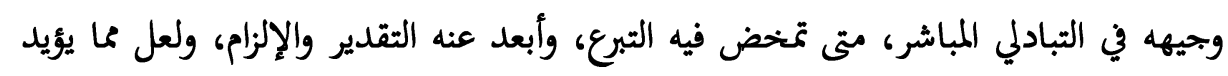

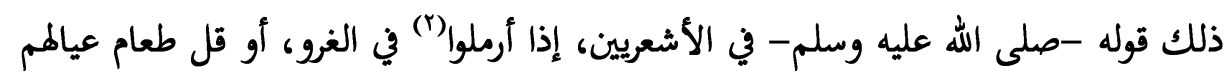

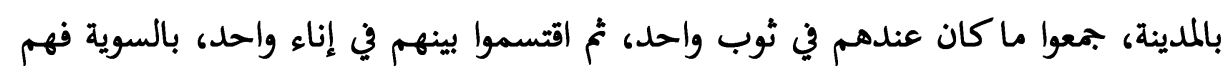

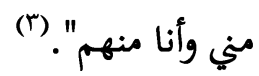
المطلب الثاني:الحكم الشرعي للتأمين التكافلي

هناك كثير من العلماء يؤيدون التأمين التكافلي، وسأعرض آرائهم وحججهم ،كما أني سأذكر آراء وحجج المعارضين لهذا النوع من التأمين ومناقشتهم فيها. أدلة القائلين بيواز التأمين التكافلي : يدور الكلام في الإحتجاج لتأمين التكافلي حول دليلين اثنين :

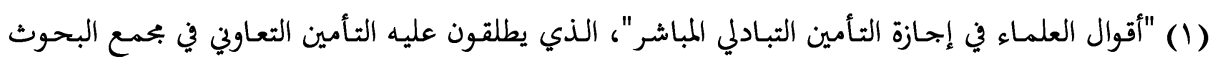

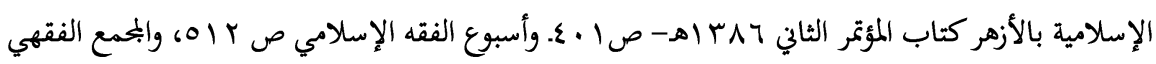

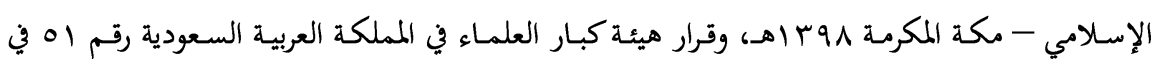

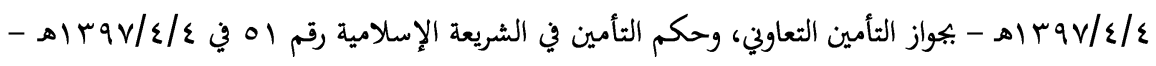

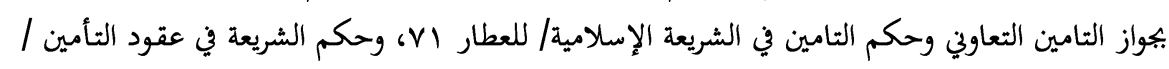

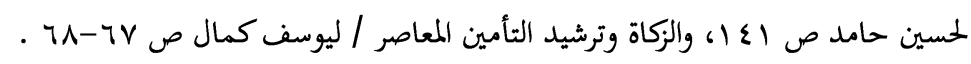

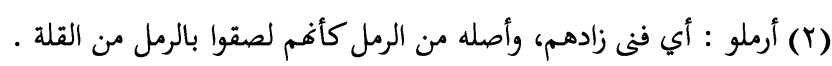

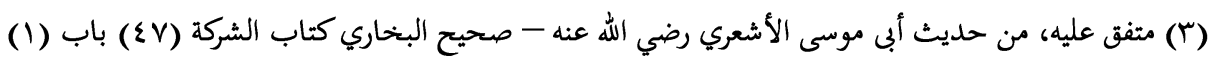

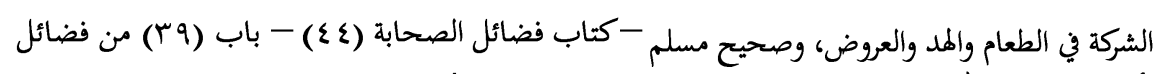

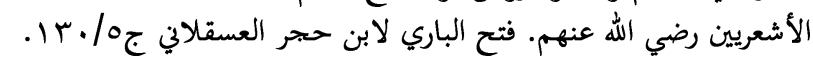


الدليل الأول : يقولون إن التأمين التكافلي من التعاون على البر، حيث إن ما

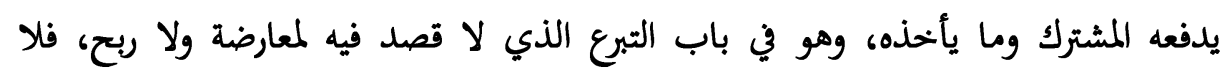

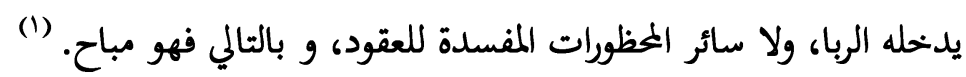
المناقشة: نوقش هذا الدليل بأن التأمين التبادلي من باب المعاوضات وليس من

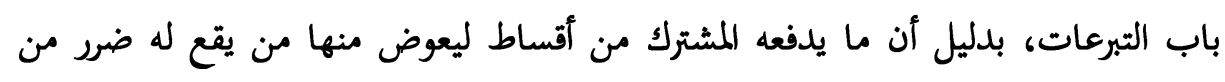

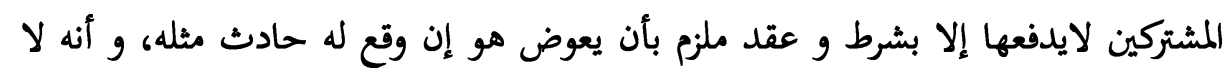

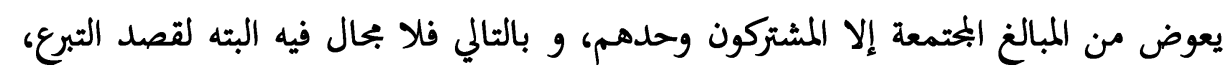
وإغما هو معاوضة نقود بنقود على وجه الإحتمال، ففيه الربا والقمار والغرر، وسائر (r) المخظورات.

الدليل الثاني : زادت مخاوف الناس الإقتصادية وتعقدت، وتقطعت صلة الأرحام

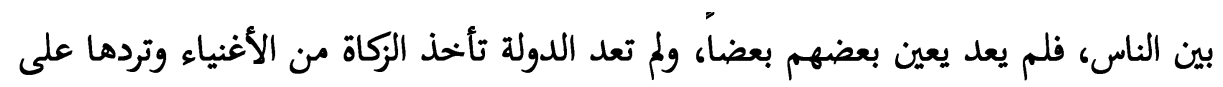

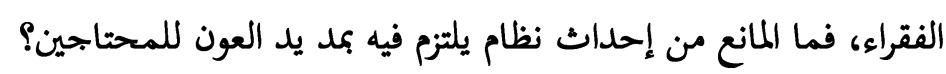

فالشريعة الإسلامية لاتمانع من إحداث معاملات تحقق مصالح المسلمين. (") المناقشة : قولكم : إن المخاوف الإقتصادية قد زادت وتعقدت، قول لايصح في

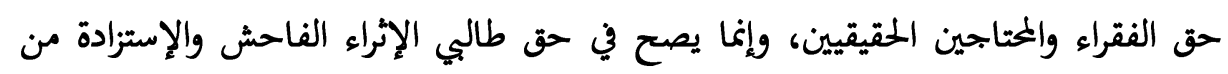

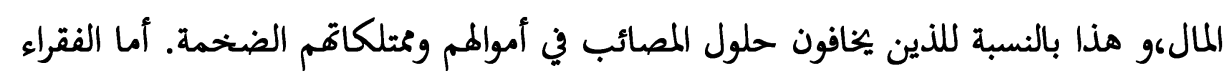
الذين لايستطيعون دفع الإشتراكات فلا مخاوف ولا تعقيد ولا أثر للتأمين فيهم في نفع ولا ضرر لعدم تعامل التأمين مع هذه الفئات أصلاً.

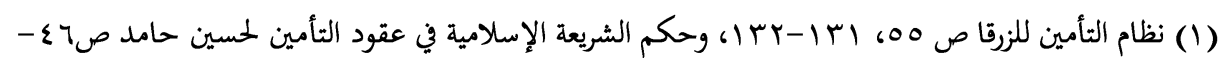

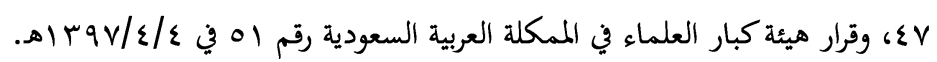

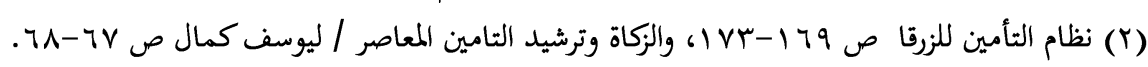

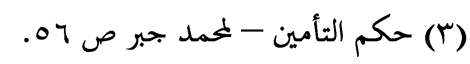


ثُم من قال إن مخاوف الحاضر قد زادت على مخاوف الماضي؟ فلعل العكس هو الصحيح. وبغض النظر عن هذا كله، فإنه لا اعتبار لشيء قد يقوم على المخظورات الشرعية، مهما كان مبرره.

أما احتجاجكم بتقطع صلة الأرحام بين الناس، وعدم مد يد العون، وإهال الدولة

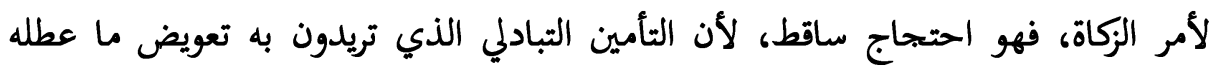

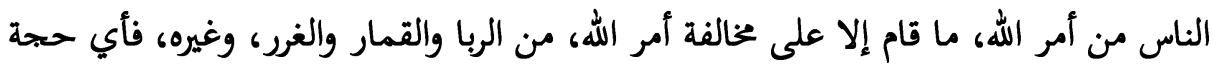

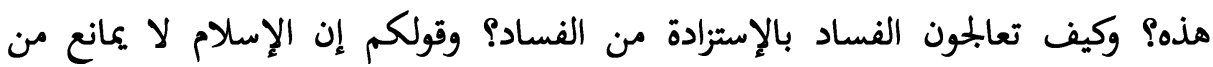
إحداث معاملات تحقق مصالح المسلمين، قول فاسد هو الآخر، وإن ظن براءته من جهله من الناس.

فكلمة "إحداث" تدل على أنه أمر مخالف لشرع الله، أما ما يوافق شرع الله فلا يوصف بالإحداث، وما شرع الله من شيء قط إلا وفيه مصلحة للعباد، وما فهى عن شيء قط إلا وفيه مفسدة للعباد، ولكن من الذي يدرك المصلحة من المفسدة سوى رب العباد،

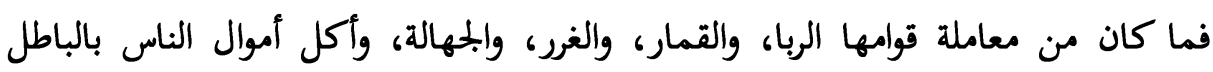

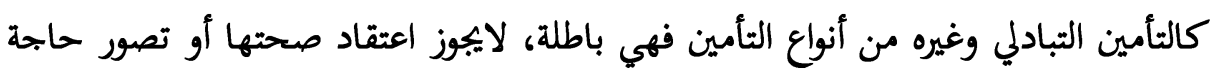

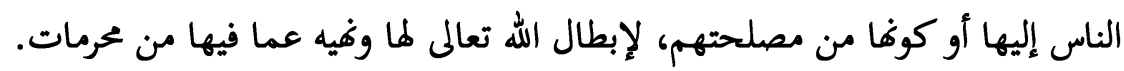
أدلة القائلين بتحريم التأمين التبادلي : استدل القائلون بتحريم التأمين التبادلي بأدلة هي أدلتهم في تحريم التأمين التجاري") حيث إن حقيقة جميع أنواع التأمين واحدة، والتفريق بينها تفريق بغير حق ، و و

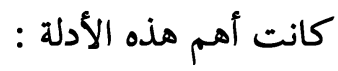

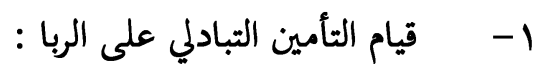




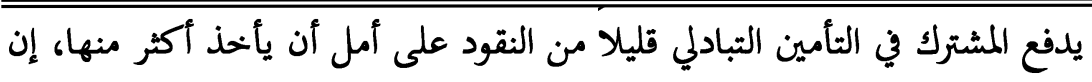
وقع له ضرر، ويتم هذا الدفع بعقد وشرط ملزم على وجه المعاوضة، وعليه فهو قائم على ربا

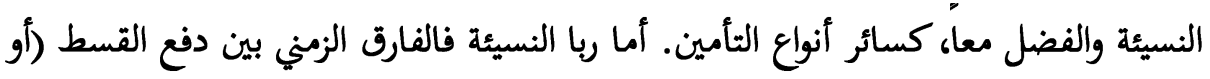
الإشتراك) واستلام العوض إن وقع الحادث، فلا مقايضة للعوضين الربويين في بحلس العقد،

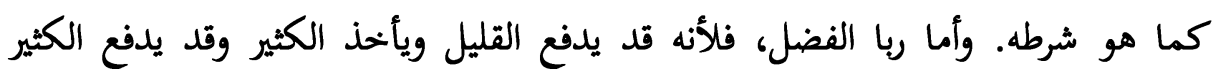
ويأخذ القليل فلا ممائلة بين العوضين النقديين. (1)

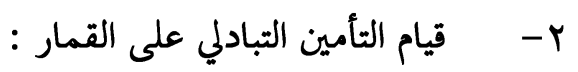

لما كان قوام التأمين التبادلي هو الإحتمال كغيره من أنواع التأمين"، فلا أحد من

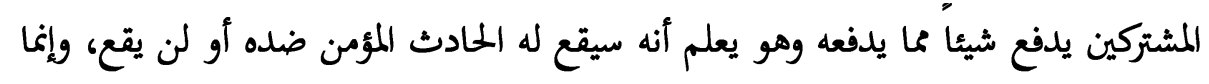

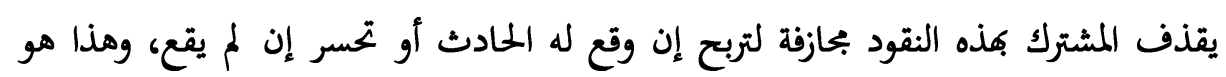
(r) عين القمار.

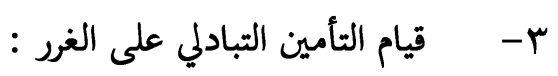

يقوم التأمين الثبادلي على الغرر الفاحش المفسد للعقود عند جميع العلماء، ذلك

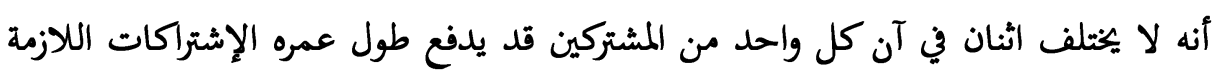

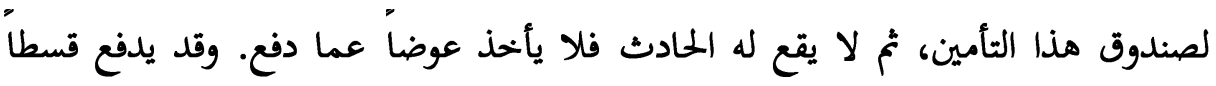

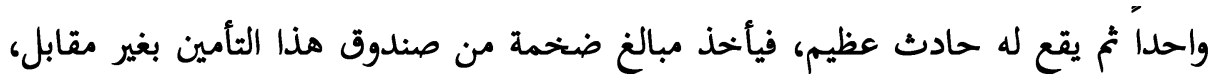

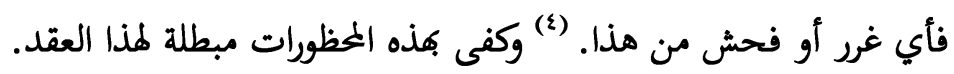
الترجيح :

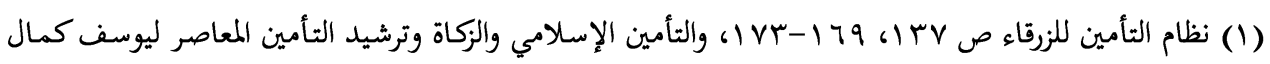

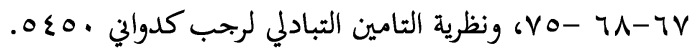


القول الراجح في هذا النوع من التأمين، هو القول الراجح في سائر أنواع التأمين،

وهو التحريء، وذلك لنفس المرجحات السابقة في التأمين التجاري. (1)

ولكني لا أوافقه في هذا الترجيح حيث أن التأمين التبادلي مباح وصريح التعامل والإلتزامات والإشتراكات لا يتخلله أي شيء من الغرر والربا والقمار وحيث أنه واضح أثناء

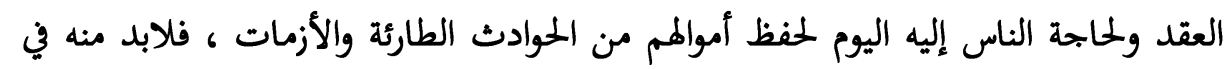

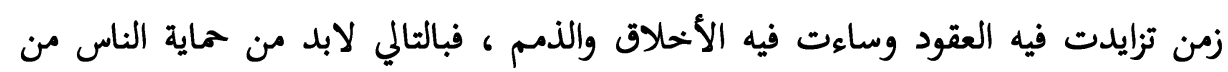

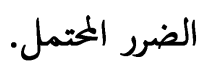


المطلب الثالث:تطبيقات الثأمين التكافلي

الشركة الإسلامية القطرية للتأمين

$\underline{(ت ج ر ب ة ~ خ ح ا ص ة) ~}$

من خلال اتفاق جماعة على التعاون في حالة وفاة أحدهم أو عجزه أو عوزه على أساس التعاون والتبرع، وعلى ضوء عقود منظمة يحدد فيها زمن وحجم ما يدفع للمستفيد آتماه

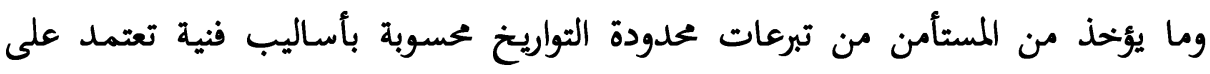
الإحصائيات والإ حتمالات ، وتصب هذه الإتفاقية في قالب شركة تشرف على هذه الأَموال وإدارتما واستثمارها وتقوم بإبرام العقود معَالناس. والأفضل أن لا تكون هذه الشركة مستقلة بل تكون فرعا من فروع شركة التأمين الإسلامية بل الأفضل أن يسمى: (التكافل الإسلامي لحماية الورثة ودفع العوز والضعف، التأمين في حالة الوفاة والتأمين لدفع العوز عند الشدة). أهداف الشركة الخاصة أو لاصندوق التكافل الإسلامي": 1 ـ ـ التعاون على البر والتقوى لتحقيق التكافل الإسلامي بين المشتركين. r - توفير الحياة الكريمة من خلال مرتب شهري أو مبلغ محدد للذرية الضعاف والورثة بعد وفاة المشترك وحمايتهم من شر العوز ومن الفقر والتشرد. r ـ دفع العوز والحاجة في حالات الشيخوخة وقطع المرتبات من خحلال دفع مبلغ إليه يعين به على حوائجه وهو قد كبرت سنه وخارت قواه وضعفت بنيته وهو في أمس الحاجة إلى

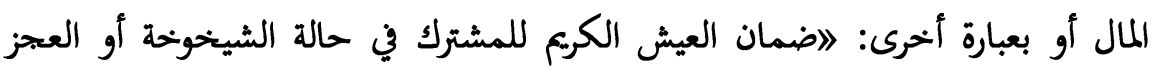

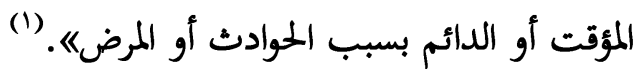
ع ـ استمار أموال المشتركين بالأساليب الشرعية. 


$$
\begin{aligned}
& 0 \text { ـ تشجيع المسلمين على الإدخار. } \\
& \text { الخطوات العملية : }
\end{aligned}
$$

1 ـ طلب اشتراك من خلال أنموذج مفصل فيه جميع أحوال الشخص وصفاته المطلوبة للتأمين عليه. r ـ تحديد قدر الإشتراك الذي يتبرع به المستأمن. r ـ أخذ قدر مقطوع من المال في مقابل الأعمال الإدارية ويسمى رسم الإشتراك. ع ـ أن تقوم الميئة المشرفة على الصندوق أو الشركة بإدارة الأموال واستثمار أقساط المؤمن لهم طبقا لأسلوب المضاربة بحيث تحدد نسبة المضاربة في العقد. ه ـ أن تقوم الميئة المشرفة بأداء التزاماتما الواجب دفعها عن طريق دفع ما تم الإتفاق عليه في

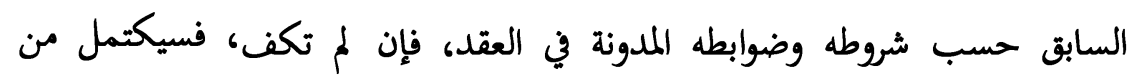

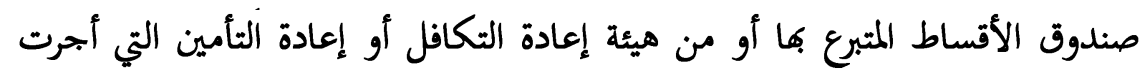

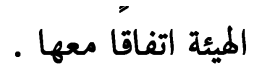

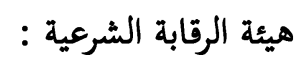

ويكون لشركة التأمين الإسلامية والتكافل الإسلامي لحماية الورثة وحالات الضعف هيئة رقابة شرعية تشرف على كل ما يتعلق بتطبيق أحكام الشريعة الإسلامية وتكون قراراتما

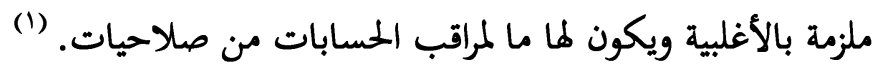
الخاتمة

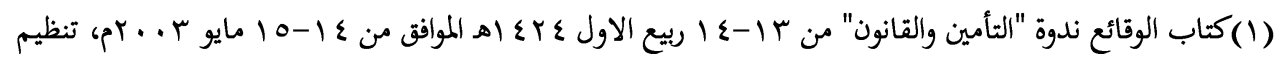

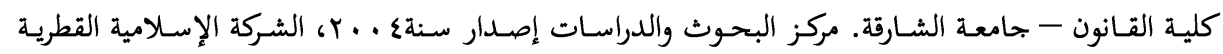

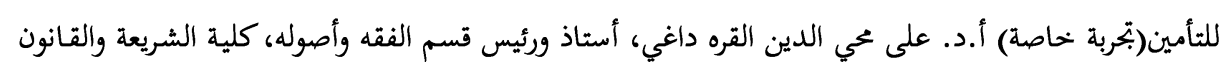

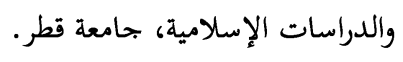


لقد فرغنا بحمد الله من دراسة موضوع " التأمين التكافلي في ضوء أحكام الشريعة الإسلامية " وفي ضوء ذلك انتهينا إلى تسجيل النتائج التالية :

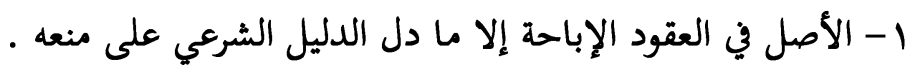

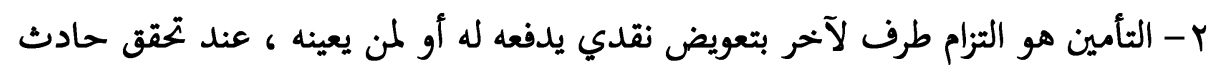

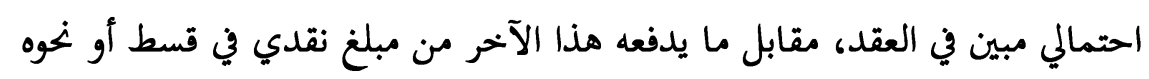

r- للتأمين أركان ثلاثة لا يقوم التأمين بدوغها هي :

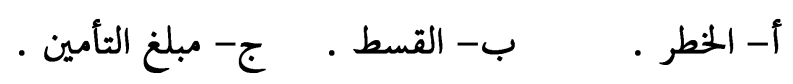

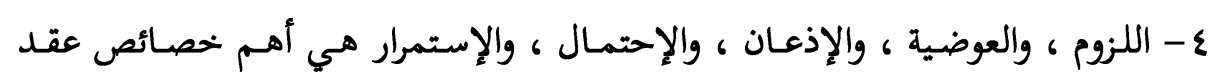
التأمين بجميع أنواعه . هـ يهدف التأمين التكافلي (التبادلي) إلى تخفيف قيمة القسط، أما التأمين الإجتماعي إلى حماية ذوي الدخل المحدود . 7- تطغى سلبيات التأمين على إيجابياته طغياناً ظاهراً .

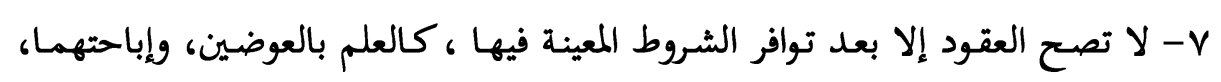

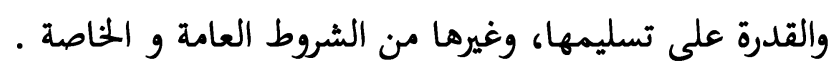

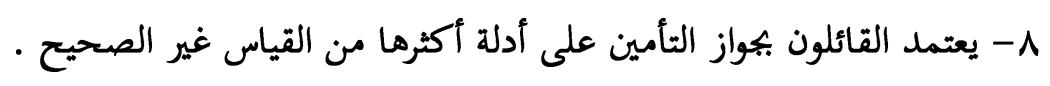

9-ولقد توصلت إلى أن هذا النظام يقوم على أسس خاصة، لا قيام له بدوها، ولكل أساس أهميته في تحقيق أمن النفوس والأموال الخاصة والعامة.

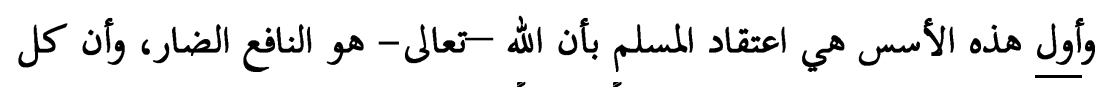

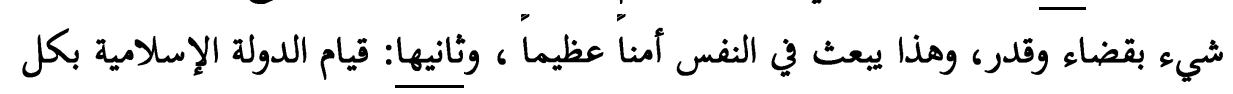

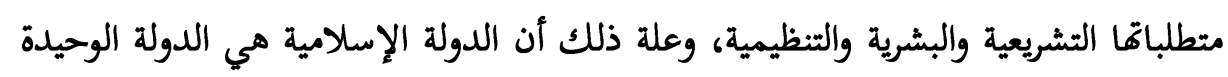

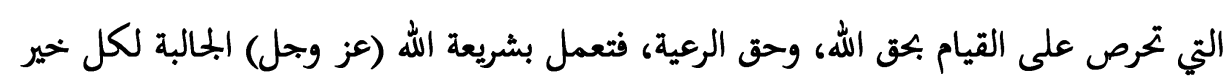

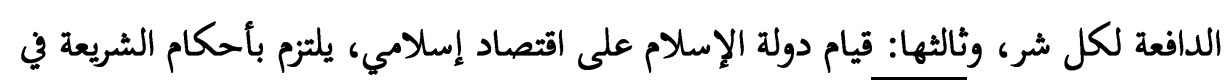


أي تعامل منه، ويهدف إلى تحقيق عيش كريم لكل مسلم، وأدناه حد الكفاية له، بذلك

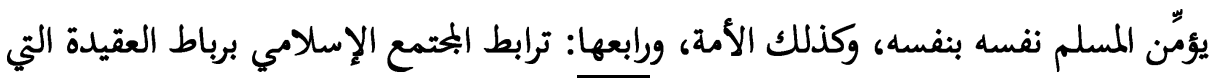

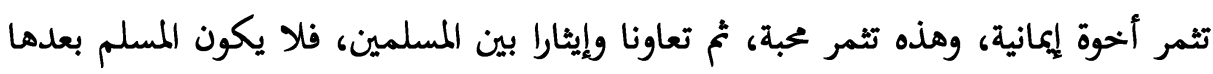
بحاجة إلى عقود التأمين الوضعي، وخحامسها: تربية إسلامية ومدنية شاملة، تقوم بها الدولة

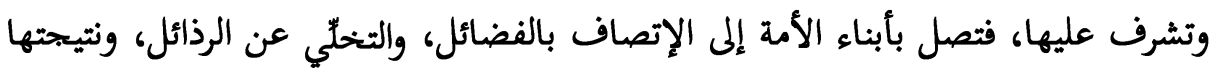

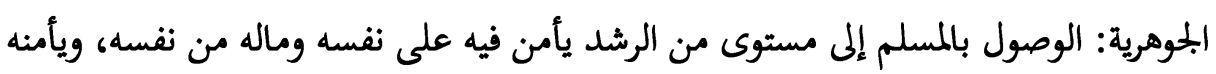
المسلمون على أنفسهم وأموالهم.

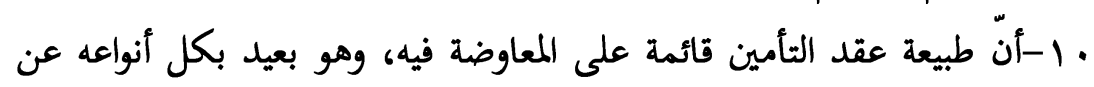

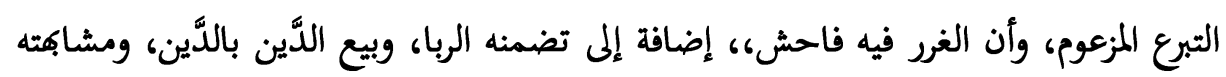
للرهان والمقامرة، ما يجعلها من المعاوضات المحرمة.

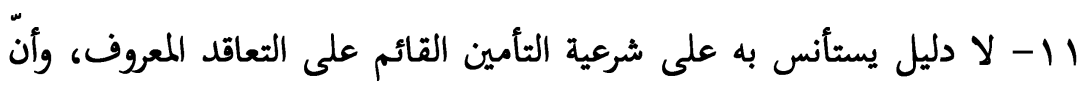

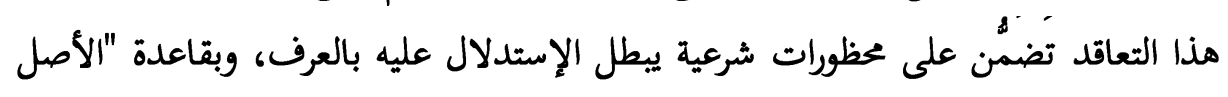

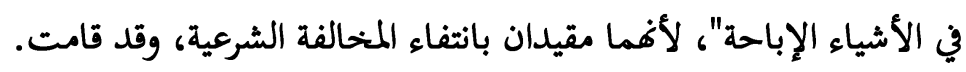

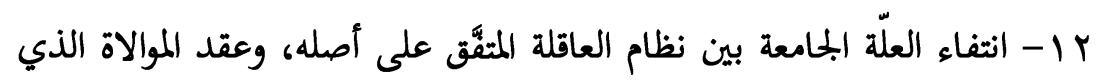

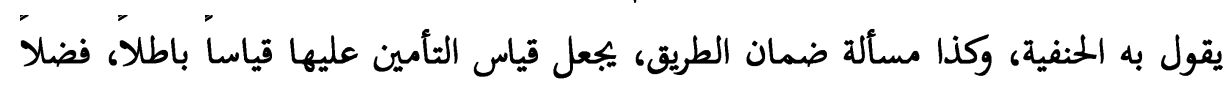
عن أن يقاس على جزء منه وهو نظام المعاشات، على اعتبار أنّ أنواع التأمين نوع واحد فيدال بالنظر إلى جوهرها وحقيقتها. با ا-وقد خحلُصت من كل ذلك إلى أنّ التأمين القائم لا يجوز الإقدام عليه دون

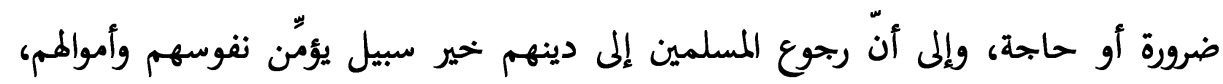

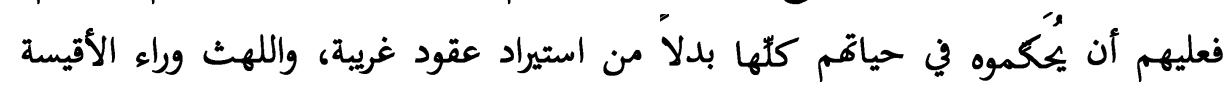

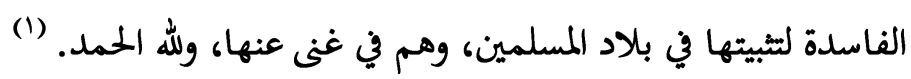

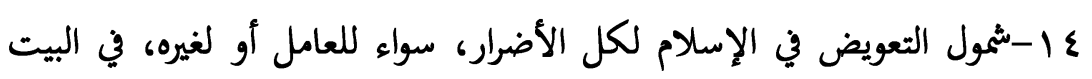

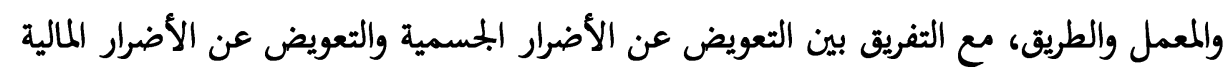


في بعض الأحكام، و تحديد مقادير التعويضات بوجه يضمن حصول المتضرر على تعويض ما لحقه من ضرر.

النتيجة المترتبة على الإلتزام بهذه الأحكام كانت حضارية و راقية، فقد ربت

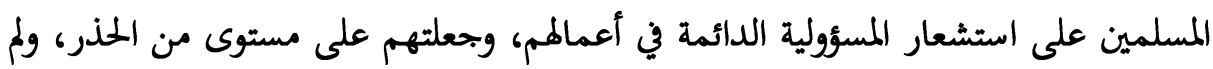

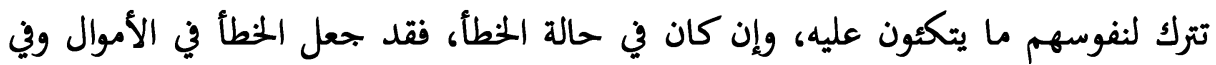
النفوس كالعمد فما يقاربما هو من استشعار بالإثم و وجوب الكفارة، فتبقى هذه النفوس في شعور دائم بالذنب. أرجو أن أكون قد وفقت في بيان نظام التأمين في الإسلام وعظمته، وحاولت التعريف بنظام التأمين الإسلامي، كما أتصوره، وبصياغتي الخاصة، فرأيت أنه: "ما شرعه الله

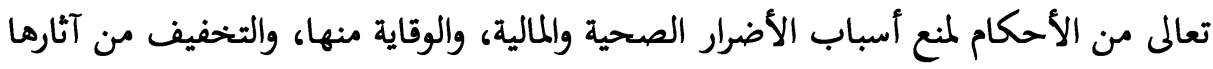
بكل الوسائل الممكنة، والتعويض عنها من مال من ترتَّب عليه، وهو الأصل، أو من مورد الزكاة وغيره، عند عجزه، فكل ذلك في ظل شريعة الإسلام ودولته وكفاءة القائمين عليها وتحقيق حدِّ الكفاية للفرد والأمة وحسن تربيتهم". هذا و أسأل الله العظيم أن يرى المسلمين الحق حقاً و و يرزقهم اتباعه ، و أن يريهم تريتم الباطل باطلا و يرزقهم إجتتابه. 


$$
\text { المراجع العلمية : }
$$

1 - كتاب الوقائع (ندوة التأمين والقانون) - كلية القانون - جامعة الشارقة. r- نظام التأمين الإسلامي - للدكتور عبد القادر جعفر - دار الكتب العلمية - الطبعة

$$
\text { الأولى سنة } 7 \text {. . r بم. }
$$

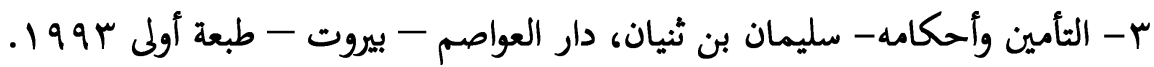

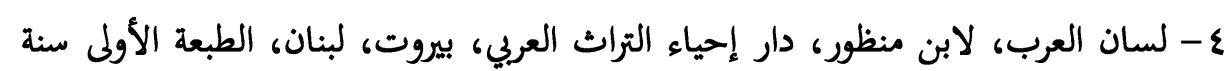
I I I I I

ه - الوسيط في شرح القانون المدني- عبد الرزاق السنهوري- دار النهضة العربية ع 97 1.

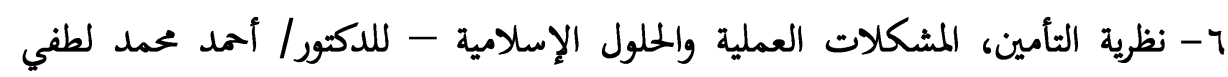

أحمد-كلية الشريعة والقانون بالدقهلية - فقه مقارن - دار الفكر الجامعي V . . r.

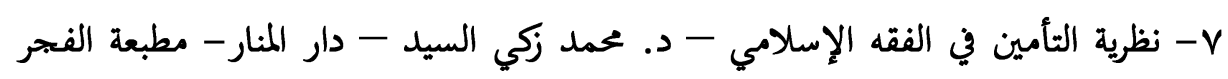

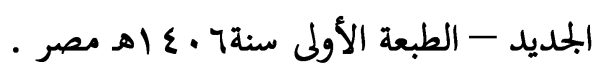

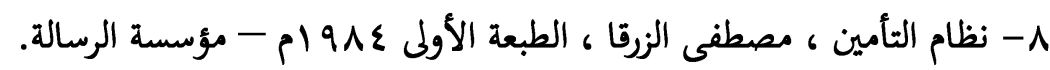
9- العقود الشرعية، عيسى عبده - دار الاعتصام.

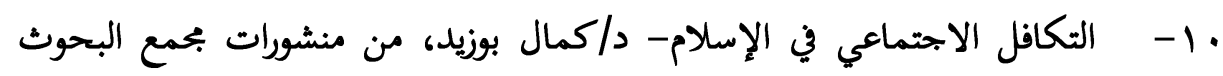
الإسلامية في المؤتمر الثاني عشر.

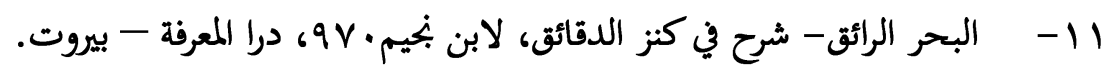

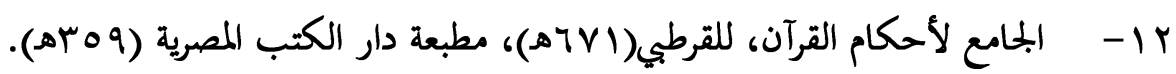

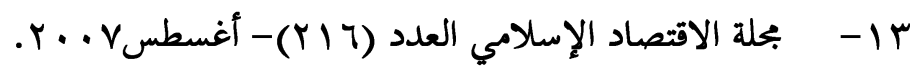

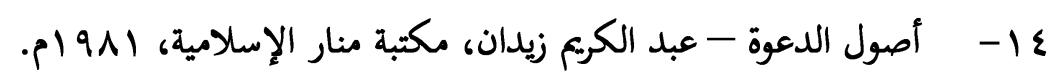

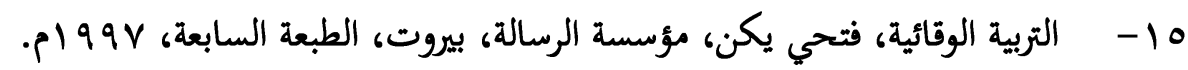

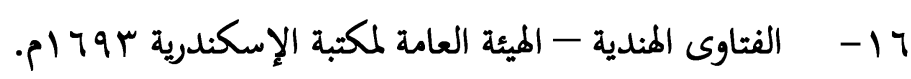

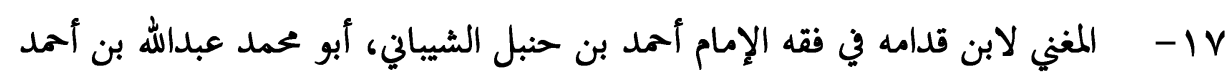

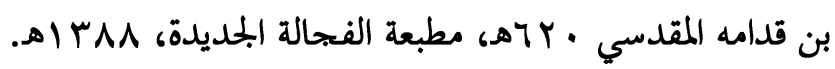


11 - حكم التأمين في الشريعة الإسلامية - لمحمد سلامه جبر - شركة الشروق للنشر مطابع القبس التجارية.

19- نظام التأمين : حقيقته والرأي الشرعية فيه، مصطفى الزرقا، مؤسسة الرسالة، بيروت، طبعة الرابعة، ع 199 1.

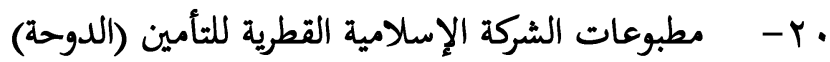

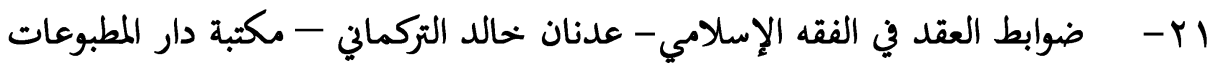

الحديثة r99 19

r Y - مراسة شرعية لأهم العقود المالية المستحدثة

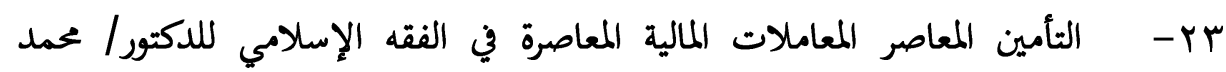
عثمان شبير، صا ـ ـ (1، طبعة دار النفائس.

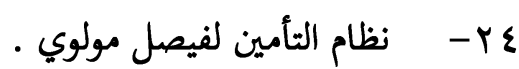

0 - - كتاب النفقات، باب إذا لم ينفق الرجل فللمرأة أن تأخذ بغير علمه ما يكفيها

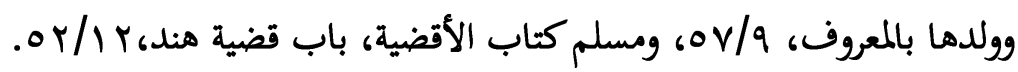

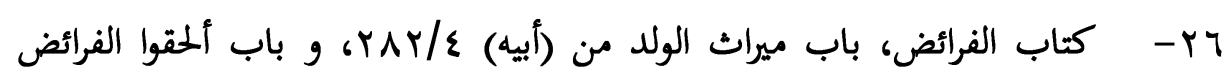

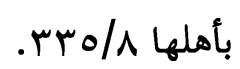

rV - - أسس التأمين التكافلي - مقال للدكتور عبد الستار أبوغدة - الأمين العام للهيئة

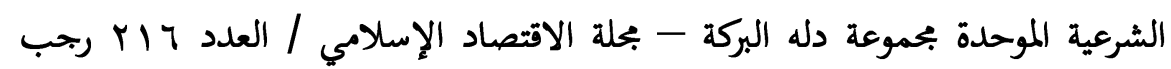

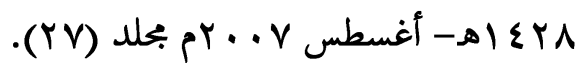

$$
\begin{aligned}
& \text { 人 }
\end{aligned}
$$

qץ- بحث (تأصيل التأمين التكافلي على أساس الوقف) للقاضي الشيخ محمد تقي العثماني.

• بـ - "أقوال العلماء في إجازة التأمين التبادلي المباشر"، الذي يطلقون عليه التأمين

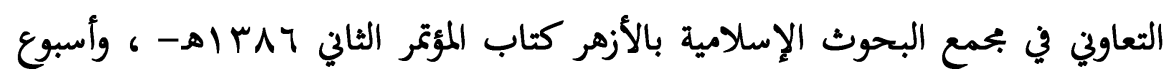

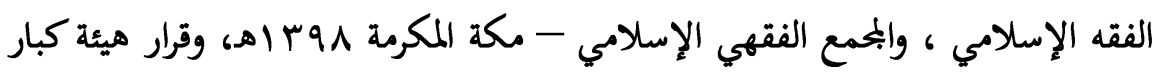


العلماء في المملكة العربية السعودية رقم اه في ع/ع/rqاهـ - بيواز التأمين

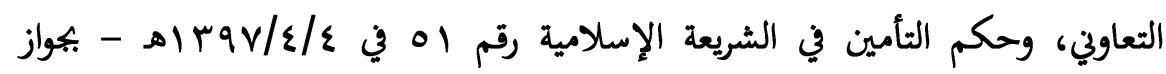

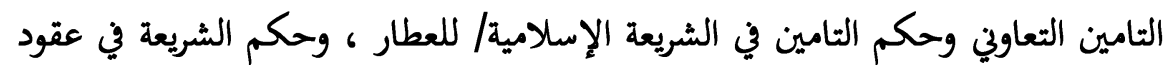
التأمين / لحسين حامد ، والزكاة وترشيد التأمين المعاصر / ليوسف كمال. 
ITV 